\title{
The composition of subduction zone fluids and the origin of the trace element enrichment in arc magmas
}

\author{
Greta Rustioni $^{1}$ D $\cdot$ Andreas Audetat $^{1} \cdot$ Hans Keppler $^{1}$
}

Received: 30 November 2020 / Accepted: 3 June 2021 / Published online: 15 June 2021

(c) The Author(s) 2021

\begin{abstract}
The partitioning of major and trace elements between eclogite and aqueous fluids with variable salinity was studied at 700-800 ${ }^{\circ} \mathrm{C}$ and 4-6 GPa in piston cylinder and multi anvil experiments. Fluid compositions were determined using the diamond trap technique combined with laser ablation ICP-MS measurements in the frozen state. In addition to $\mathrm{NaCl}, \mathrm{SiO}_{2}$ is the main solute in the fluids. The fluid/eclogite partition coefficients of the large ion lithophile elements (LILE), such as Rb, $\mathrm{Cs}, \mathrm{Sr}$, and $\mathrm{Ba}$ as well as those of the light rare earths (LREE), of $\mathrm{Pb}$, and of $\mathrm{U}$ increase by up to three orders of magnitude with salinity. These elements will therefore be efficiently transported by saline fluids. On the other hand, typical high field strength elements, such as $\mathrm{Ti}, \mathrm{Nb}$, and $\mathrm{Ta}$, are not mobilized even at high salinities. Increasing temperature and pressure gradually increases the partitioning into the fluid. In particular, Th is mobilized by silica-rich fluids at $6 \mathrm{GPa}$ already at low salinities. We show that we can fully reproduce the trace element enrichment pattern of primitive arc basalts by adding a few percent of saline fluid (with 5-10 wt $\% \mathrm{Cl}$ ) released from the basaltic slab to the zone of melting in the mantle wedge. Assuming $2 \mathrm{wt} \%$ of rutile in the eclogite equilibrated with the saline fluid produces a negative $\mathrm{Nb}$ Ta anomaly that is larger than in most primitive arc basalts. Therefore, we conclude that the rutile fraction in the subducted eclogite below most arcs is likely $<1 \mathrm{wt} \%$. In fact, saline fluids would even produce a noticeable negative $\mathrm{Nb} \mathrm{Ta}$ anomaly without any rutile in the eclogite residue. Metasomatism by sediment melts alone, on the other hand, is unable to produce the enrichment pattern seen in arc basalts. We, therefore, conclude that at least for primitive arc basalts, the release of hydrous fluids from the basaltic part of the subducted slab is the trigger for melting and the main agent of trace element enrichment. The contribution of sediment melts to the petrogenesis of these magmas is likely negligible. In the supplementary material, we provide a "Subduction Calculator" in Excel format, which allows the calculation of the trace element abundance pattern in primitive arc basalts as function of fluid salinity, the amount of fluid released from the basaltic part of the subducted slab, the fluid fraction added to the source, and the degree of melting.
\end{abstract}

Keywords Subduction zone fluids $\cdot$ Fluid/eclogite partitioning $\cdot$ Arc magmas $\cdot$ Salinity $\cdot$ Trace elements $\cdot \mathrm{Nb}$ Ta anomaly Primitive arc basalts

\section{Introduction}

Magma generation in subduction zones is likely the main mechanism for the growth of the continental crust since the onset of plate tectonics (e.g. Hawkesworth et al. 2019). While early studies assumed that these magmas were formed

Communicated by Dante Canil.

Greta Rustioni

greta.rustioni@uni-bayreuth.de

1 Bayerisches Geoinstitut, Universität Bayreuth, 95440 Bayreuth, Germany by direct melting of the subducted basaltic crust (Green and Ringwood 1968), recent thermal models (Syracuse et al. 2010) imply that this is only possible under exceptional circumstances for very young and hot slabs. Direct slab melting within steeper geothermal gradients may, however, have produced the Archean TTG (tonalite trondjemite-granodiorite) suite that is a main component of the earliest continental crust (Rapp et al. 2003). Since the subduction of cold material from Earth's surface actually reduces the temperature of the surrounding mantle, there is a general consensus that magma formation in subduction zones cannot be caused by elevated temperatures. Rather, melting point depression by the addition of water to the mantle wedge is likely the cause 
of magmatic activity, consistent with the generally elevated water contents in arc magmas (Métrich and Wallace 2008). Water also appears to correlate with the oxidation state of the magmas (Kelley and Cottrell 2009). This may be due to the effect of water itself or to some oxidized species, such as sulfate, that was transported together with the water (e.g. Bénard et al. 2018). Many models therefore assume that aqueous fluids released by the breakdown of hydrous minerals in the subducted slab infiltrate into the mantle wedge and trigger melting (e.g. Gill 1981; Arculus and Powell 1986; Tatsumi 1989; Peacock 1990). This idea would be generally consistent with the typical trace element enrichment pattern seen in arc magmas (e.g. Kelemen et al. 2005), which features strong enrichments in large ion lithophile (LILE) elements, such as $\mathrm{Rb}, \mathrm{Cs}, \mathrm{Sr}$, and $\mathrm{Ba}$, which are usually considered to be soluble in aqueous fluids, while the poorly soluble high field strength elements (HFSE), such as Ti, Zr, Hf, Nb, and Ta are depleted. Accordingly, many experimental studies have been carried out in the last few decades to constrain the composition of aqueous fluids in equilibrium with minerals of the subducted slab at high pressures and temperatures (Brenan et al. 1994, 1995; Keppler 1996; Stalder et al. 1998; Johnson and Plank 1999; Kessel et al. 2005; Bali et al. 2011, 2012; Tsay et al. 2014, 2017). Several of the earlier investigations were hampered by technical problems related to the difficulty in determining fluid compositions quenched from high-pressure experiments. Overall, the available data on the partitioning of trace elements between purely aqueous fluids and eclogite mostly suggest that such fluids are not very efficient in transporting trace elements, with the exception of some alkalis and alkaline earths. Therefore, a common notion in the recent literature is that aqueous fluids are "too dilute" to cause the trace element enrichment pattern seen in typical arc magmas (e.g. Hermann et al. 2006; Spandler and Pirard 2013).

The perceived inability of aqueous fluids to generate the trace element enrichment seen in arc magmas has led to alternative ideas on the nature of the phase that transports water from the subducted slab to the zone of melting in the mantle wedge. One possibility could be supercritical fluids intermediate in composition between aqueous fluids and silicate melts (e.g. Bureau and Keppler 1999; Portnyagin et al. 2007). Indeed, experimental data (Kessel et al. 2005) suggests that the capability of such fluids to transport many trace elements greatly increases with bulk solute content. However, as the composition of the mobile phase becomes more melt-like, the strong fractionation between LILE elements (e.g. Ba) and HFSE elements (e.g. Nb), which is characteristic for arc magmas, also diminishes. Indeed, variations in the $\mathrm{Ba} / \mathrm{Nb}$ ratio of arc magmas have sometimes been attributed to variable contributions of "shallow" and "deep" fluid components (Pearce et al. 2005), the deep fluid components perhaps being rather silica-rich.
Some recent studies have suggested that sediment melts may be the main agent for the metasomatism of the mantle wedge above the subducted slab and serve as the ultimate trigger for arc magmatism (e.g. Kelemen et al. 2005; Hermann et al. 2006; Hermann and Rubatto 2009; Skora and Blundy 2010; Behn et al. 2011; Spandler and Pirard 2013; Skora et al. 2015). The correlation of trace element (e.g. Th/ La) and isotope ratios of magmas and subducted sediments in some arcs supports some involvement of sediment melts or perhaps of fluids released from the sediment (e.g. Armstrong 1971; Turner and Foden 2001; Plank 2005). Proposing sediment melts as the main trigger of arc magmatism, however, is difficult to reconcile with the striking similarity in the trace element pattern of primitive arc basalts worldwide (see the compilation in Kelemen et al. 2005), irrespective of the presence, absence, nature, and amount of sediment subducted. Also, the rather viscous nature of silica-rich sediment melts does not match with the short timescales for fluid transfer from the slab to the zone of melting inferred from radioactive disequilibria ( $<30,000$ to 120,000 years, e.g., Hawkesworth et al. 1997; Turner and Foden 2001). However, sediment melts or aqueous fluids released from sediments may contribute to the chemical transport from the subducted slab to the zone of melting in the mantle wedge. Variations in magma composition within a volcanic arc are therefore often interpreted in terms of variable contributions of aqueous fluids and sediment melts (e.g. Elliott et al. 1997; Class et al. 2000; Turner and Foden 2001; Zamboni et al. 2016). On the other hand, a recent study of Klaver et al. (2020) using $\delta^{88 / 86} \mathrm{Sr}$ as a tracer of $\mathrm{Sr}$ concluded that the slab-derived fluid accounts for $>70 \%$ of the Sr budget of the Mariana and Aegean arc lavas. Considering that the Aegean arc subducts 3-6 km of Sr-rich calcareous sediments, this observation casts severe doubts on the perceived importance of the sediment melts for arc magma generation.

To better constrain the transport processes in subduction zones and to resolve some of the contradictions mentioned above, it appears necessary to re-investigate the partitioning of trace elements between minerals and aqueous fluids. In a recent study, Rustioni et al. (2019) demonstrated that the fluid/eclogite partition coefficient of many trace elements increases by up to three orders of magnitude upon the addition of chloride to the system. Indeed, compared to MORB, the $\mathrm{Cl}$ abundance in primitive arc basalts is elevated by orders of magnitude. Since $\mathrm{Cl}$ is a trace component in the normal upper mantle $(0.9 \pm 0.63 \mathrm{ppm}$, Saal et al. 2002), it is plausible that this $\mathrm{Cl}$ was introduced into the zone of melting by aqueous fluids from the subducted slab. Métrich and Wallace (2008) demonstrated that the $\mathrm{Cl} / \mathrm{H}_{2} \mathrm{O}$ ratio preserved in undegassed melt inclusions from primitive arc basalts implies fluid salinities typically ranging between 5 and 15 $\mathrm{wt} \% \mathrm{NaCl}$. Limited data from fluid inclusions in xenoliths affected by subduction fluids also suggest similar salinities 
(Kawamoto et al. 2013). Complexing of trace elements by $\mathrm{Cl}^{-}$in subduction zone fluids may therefore have a strong effect on chemical transport in subduction zones. The experimental data obtained by Rustioni et al. at $4 \mathrm{GPa}$ and $800{ }^{\circ} \mathrm{C}$ suggest that saline fluids released from the basaltic part of the subducted slab may well account for the typical trace element enrichment pattern seen in primitive arc magmas. This would imply that the relative contribution of aqueous fluids and sediment melts to chemical transport below the arc needs to be reconsidered. In this study, we build on the groundwork laid forth by Rustioni et al. (2019) by providing new data on the temperature and pressure dependence of fluid/eclogite partitioning for a large suite of trace elements as well as for the major silicate components. Moreover, we incorporate all results into a model developed to asses melt composition as a function of fluid salinity, fluid fraction released from the slab, and fluid fraction entering the zone of melting.

\section{Experimental methods}

\section{Starting materials and sample preparation}

To reproduce the composition of the basaltic portion of subducting oceanic slabs, a K-free MORB glass was synthesized, with a composition similar to that of Kessel et al. (2005). This glass was doped with 25 trace elements by the addition of $2 \mathrm{wt} \%$ of a trace element-rich synthetic diopside glass. About $1 \mathrm{wt} \%$ of garnet seeds, selected from Grytting (Norway) eclogite and crushed into a fine powder, were also added to the starting material in order to enhance garnet growth during the experiments. Aqueous solutions with salinities of $1,5,10$, and $15 \mathrm{wt} \%$ were produced by dissolution of precisely weighed amounts of pure $\mathrm{NaCl}$ in distilled water. Two trace element doped solutions, obtained by mixing ICP-MS calibration solutions, were used in combination with the undoped MORB glass to carry out reversed experiments. Complete analyses of all starting materials are given in Table S-2 in the supplementary material. For more information about the preparation of the starting materials used in this study see Rustioni et al (2019).

To perform high-pressure experiments, the starting glass was loaded together with water or saline solutions in Pt or Au capsules. A thin layer of diamond powder was sandwiched between two layers of MORB glass to provide empty pores for fluid circulation. About $1 \mathrm{~mm}$ of space was left empty at the top of the capsules to avoid fluid losses that may be caused by heating during the welding of the top lid. Each capsule was weighed before and after welding to ensure that no major fluid loss occurred. For piston cylinder experiments, cylindrical capsules with an outer diameter of $5 \mathrm{~mm}, 0.2 \mathrm{~mm}$ wall thickness, and $10 \mathrm{~mm}$ length were employed. Those capsules typically contained about $50 \mathrm{mg}$ of solution, $125 \mathrm{mg}$ of MORB glass, and $60 \mathrm{mg}$ of diamond powder. For multi anvil experiments, Pt tubes with $4 \mathrm{~mm}$ outer diameter, $0.15 \mathrm{~mm}$ wall thickness, and $5 \mathrm{~mm}$ length together with lids were used as capsules. They usually contained about $12 \mathrm{mg}$ of fluid, $30 \mathrm{mg}$ of MORB glass, and $15 \mathrm{mg}$ of diamond powder. After the sealing of the top lid and before multi anvil experiments, the capsules were precompressed to a length of $4 \mathrm{~mm}$ to fit into the assembly. This procedure eliminates the empty space originally left at the top of the capsules, thus maximizing the amount of material that can be loaded in each experiment.

\section{Piston cylinder experiments}

High-pressure experiments at $4-5 \mathrm{GPa}$ and $700-800{ }^{\circ} \mathrm{C}$ were performed using an end-loaded piston-cylinder apparatus. Low-friction $1 \frac{1}{2}$ inch $\mathrm{MgO}-\mathrm{NaCl}$ assemblies with a stepped graphite furnace were used. A constant friction correction of - $0.12 \mathrm{GPa}$ was applied to the nominal pressures, as calibrated by the quartz-coesite transition near $3 \mathrm{GPa}$ and by the density of synthetic fluid inclusions at $800{ }^{\circ} \mathrm{C}$ and $0.5-1.0$ GPa. The temperature was measured with an S-type thermocouple $(\mathrm{Pt} / \mathrm{Pt}-\mathrm{Rh})$ and monitored by a Eurotherm controller. Long compression and decompression durations, up to $20 \mathrm{~h}$, were applied to reduce the deformation of the capsule. Temperature was increased after compression with a heating rate of $100{ }^{\circ} \mathrm{C} / \mathrm{min}$. Fluctuations in the temperature of $\pm 30{ }^{\circ} \mathrm{C}$ over a period of $8 \mathrm{~h}$ were applied to most of the experiments to enhance mineral growth by Ostwald ripening. Experiments were quenched by switching off the electrical power at constant pressure before decompression. Total run durations ranged between 3 and 7 days. These run durations are sufficient to attain chemical equilibrium between fluid and minerals, as demonstrated by Rustioni et al. (2019). The oxygen fugacity in these experiments was not controlled, but it is likely somewhere in the range between the quartzfayalite-magnetite and the $\mathrm{Ni}-\mathrm{NiO}$ buffer. However, with the only notable exception of $\mathrm{U}$, the oxidation state of all trace elements studied here is expected to be independent of oxygen fugacity.

\section{Multi-anvil experiments}

Experiments at $6 \mathrm{GPa}$ and $800{ }^{\circ} \mathrm{C}$ were carried out in a Walker-type multi-anvil apparatus following the pressure calibration of Keppler and Frost (2005). We used tungsten carbide cubes as secondary anvils, pyrophyllite gaskets, and a 25/15 (octahedral edge length/truncation edge length in $\mathrm{mm}$ ) assembly consisting of an outer $\mathrm{MgO}$ octahedron that contains a $\mathrm{ZrO}_{2}$ sleeve, a stepped graphite furnace and an inner $\mathrm{MgO}$ sleeve, in which the sample capsule is kept at the center by $\mathrm{MgO}$ spacers, and Mo caps. All $\mathrm{MgO}$ parts 
were heated to $1000{ }^{\circ} \mathrm{C}$ for $1 \mathrm{~h}$ to remove eventual moisture before being assembled. Experiments were compressed and decompressed within $15 \mathrm{~h}$. As for piston cylinder experiments, temperature was raised at a rate of $100{ }^{\circ} \mathrm{C} / \mathrm{min}$ after compression. A D-type (W97Re3-W75Re25) thermocouple was employed to monitor the temperature during experiments. High pressure and temperature conditions were maintained for 3-5 days. The runs were terminated by rapid quench before decompression. A summary of all experimental details for the high-pressure experiments is compiled in Table S-1 of the supplementary online material.

\section{Laser ablation ICP-MS analyses}

Both fluid and mineral compositions were determined by laser ablation inductively coupled plasma mass spectrometry (LA-ICP-MS). After high pressure experiments, the recovered capsules were cooled in $\mathrm{N}_{2}$ and cut in half in the frozen state to expose the diamond trap. The diamond layer still containing the frozen fluid was then analyzed along two perpendicular transects by means of a LA-ICP-MS instrument equipped with a freezing chamber able to maintain the sample at a temperature of $-0{ }^{\circ} \mathrm{C}$ during the entire measurement (Kessel et al. 2004). The instrument used consists of a $193 \mathrm{~nm}$ ArF GeolasPro laser ablation unit (Coherent, USA) connected to an Elan DRC-e quadrupole ICP-MS unit (Perkin Elmer, Canada). Chlorine (or Cs in experiments with pure water) was used as an internal standard for the fluid analysis. This is justified since the solubility of $\mathrm{Cl}$ in garnet and pyroxene in equilibrium with a saline fluid is extremely low, in the order of a few ppm (Bernini et al. 2013). Chlorine contents in the fluid phase were corrected for the dilution effect by dissolved solutes (mostly $\mathrm{SiO}_{2}$ ), as determined from the diamond trap analyses. After the determination of fluid composition, each capsule was impregnated in epoxy resin and polished. Garnet, omphacite and rutile crystals were then analyzed again using LA-ICP-MS. In each analysis Nist610 and a well-calibrated, natural Afghanite was used as external standards. For further details about the experimental and analytical procedures see Rustioni et al. (2019, 2021).

\section{Calculation of bulk fluid/eclogite partition coefficients}

Fluid/mineral partition coefficients $D^{\text {fluid/mineral }}$ were obtained from the experimental data according to $D^{\text {fluid/mineral }}=c_{\text {fluid }} / c_{\text {mineral }}$, where $c_{\text {fluid }}$ and $c_{\text {mineral }}$ are the concentrations of a given element in the coexisting fluid and mineral. Bulk fluid/eclogite partition coefficients $\left(D^{\text {fluid/eclogite }}\right)$ were calculated from the individual fluid/mineral partition coefficients according to $\left(1 / D^{\text {fluid/eclogite }}\right)=\Sigma$ $\left(x_{\text {mineral }} / D^{\text {fluid/mineral }}\right)$, where $x_{\text {mineral }}$ are the weight fractions of each mineral. To constrain the sole effect of changes in fluid salinity on the trace element partitioning behavior, in these calculations, the eclogite modal composition was fixed at 59\% omphacite, $39 \%$ garnet and $2 \%$ rutile. In the following text, $D^{\text {fluid/eclogite }}$ always refers to a bulk fluid/eclogite partition coefficient for this mineralogy.

\section{Results}

\section{Bulk fluid compositions}

During the runs, the glassy starting material always transformed into a well-crystallized eclogitic assemblage of omphacite + garnet + rutile \pm kyanite. Representative microprobe analyses of these phases and images of the run products are given in Rustioni et al. (2019) and in the supplementary online material. Experiments starting with trace elements doped into the solids give results consistent with reversed runs, where the trace elements were doped into the solution (see also Rustioni et al. 2019). The compositions of minerals were uniform throughout the entire capsule (see also Figure 7 in Rustioni et al. 2021). In accordance with the results from the reversed experiments, this provides strong evidence that chemical equilibrium was reached. The major element composition of the fluid coexisting with the eclogitic assemblage are shown in Figs. 1 and 2 for each experiment; see also Table S-3 in the supplementary online material. The total solute contents shown include $\mathrm{SiO}_{2}$, $\mathrm{Al}_{2} \mathrm{O}_{3}, \mathrm{Na}_{2} \mathrm{O}, \mathrm{CaO}, \mathrm{FeO}, \mathrm{MgO}$, and $\mathrm{Cl}$. These totals are highly dependent on fluid salinity, ranging from an average of about $20 \mathrm{wt} \%$ solutes in experiments conducted at $4 \mathrm{GPa}$ and $800{ }^{\circ} \mathrm{C}$ without $\mathrm{NaCl}$ to an average of about $40 \mathrm{wt} \%$ in experiments with more than $6 \mathrm{wt} \%$ of $\mathrm{Cl}$ at the same conditions. As illustrated by Fig. 1, an increase in temperature of $100{ }^{\circ} \mathrm{C}$ at $4 \mathrm{GPa}$ significantly enhances bulk solubility, yielding a total solute content of about $5 \mathrm{wt} \%$ at $700{ }^{\circ} \mathrm{C}$, but about $20 \mathrm{wt} \%$ at $800{ }^{\circ} \mathrm{C}$ for a Cl-free fluid. The effect of salinity is similar at both temperatures.

The major solute in all experiments is $\mathrm{SiO}_{2}$, which represents on average $65 \%$ of the total solute content. At 4 $\mathrm{GPa}, \mathrm{SiO}_{2}$, together with $\mathrm{Al}_{2} \mathrm{O}_{3}$, does not show a significant increase in solubility upon addition of $\mathrm{Cl}$ to the fluid, both oxides being more sensitive to temperature. On the other hand, the solubilities of $\mathrm{Na}_{2} \mathrm{O}, \mathrm{CaO}, \mathrm{FeO}$, and $\mathrm{MgO}$ markedly increase with fluid salinity. In particular, $\mathrm{Na}_{2} \mathrm{O}$ concentration is mostly a function of $\mathrm{Cl}$ content in the fluid, while $\mathrm{CaO}, \mathrm{FeO}$, and $\mathrm{MgO}$ solubilities are also affected by temperature. The nearly linear increase of $\mathrm{Na}_{2} \mathrm{O}, \mathrm{CaO}$, and $\mathrm{MgO}$ concentrations in the fluid at $4 \mathrm{GPa}$ is most likely due to the formation of some undissociated species with a metal:chloride ratio of $1: 1$ in the fluid, such as $\mathrm{NaCl}, \mathrm{Ca}(\mathrm{OH})$ $\mathrm{Cl}$, and $\mathrm{Mg}(\mathrm{OH}) \mathrm{Cl}$ (e.g. Barnes et al. 2018). Undissociated 

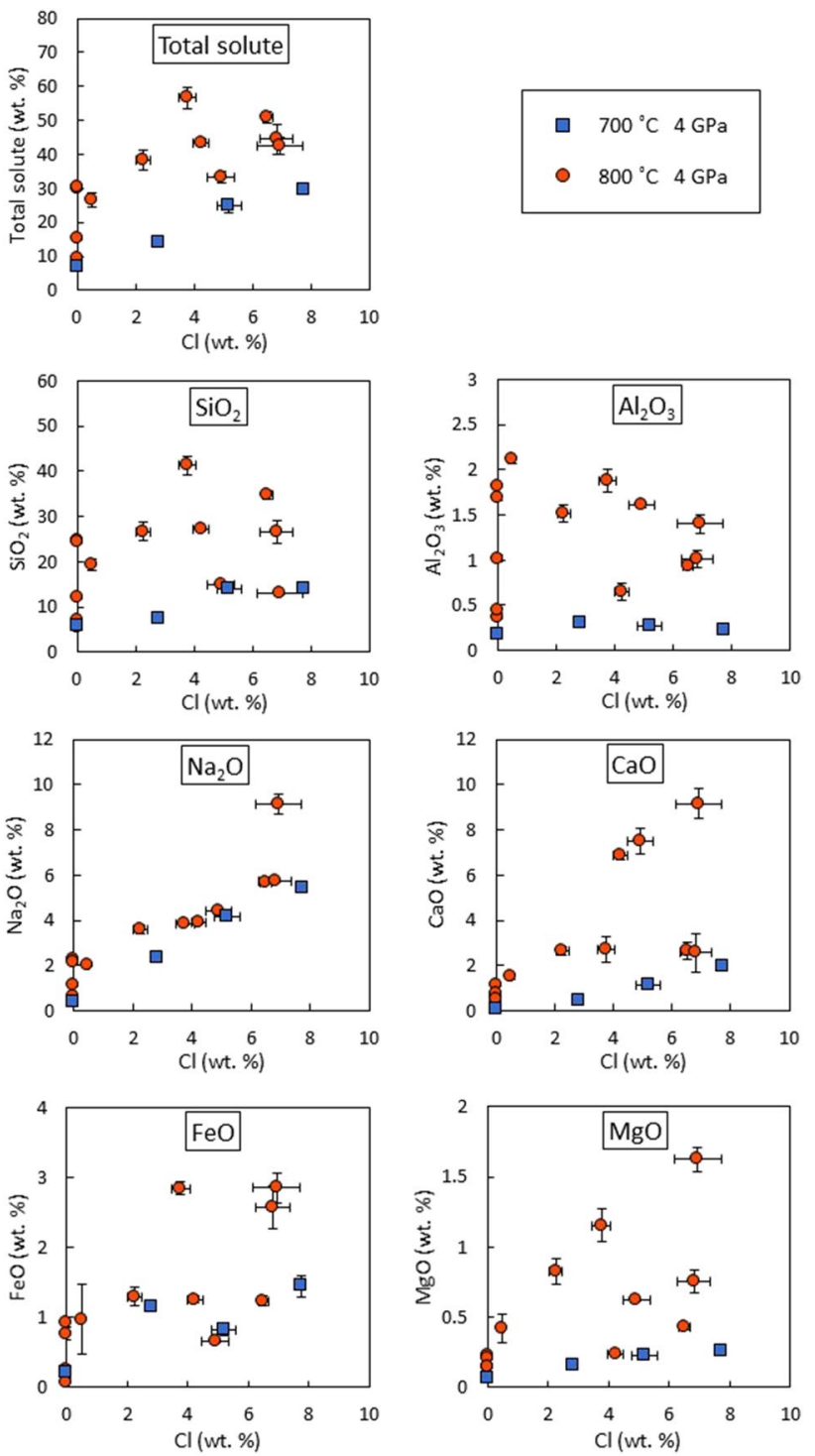

Fig. 1 Bulk composition of saline fluids in equilibrium with an eclogitic assemblage from high-pressure experiments at $4 \mathrm{GPa}$ and 700 $800{ }^{\circ} \mathrm{C}$. "Total solute" is the sum of all oxide components plus $\mathrm{Cl}$, with a slight negative correction for the fact that $1 \mathrm{Cl}^{-}$replaces $1 / 2 \mathrm{O}^{2-}$ in the fluid

species are favored by the reduced dielectric constant of water under typical subduction zone conditions; however, some dissociation of these species is still expected to occur (e.g. Barnes et al. 2018; Keppler 2017; Manning and Frezzotti 2020). The involvement of $\mathrm{OH}$ ions in complexing is plausible, as the fluids are expected to be slightly alkaline due to interaction with the silicate minerals (Galvez et al. 2016).

With pressure increasing to 5 and $6 \mathrm{GPa}$, the dependence of fluid composition on salinity changes (Fig. 2). $\mathrm{SiO}_{2}$ and $\mathrm{Al}_{2} \mathrm{O}_{3}$ now markedly decrease with salinity, which also translates into a decrease of bulk solute at 6
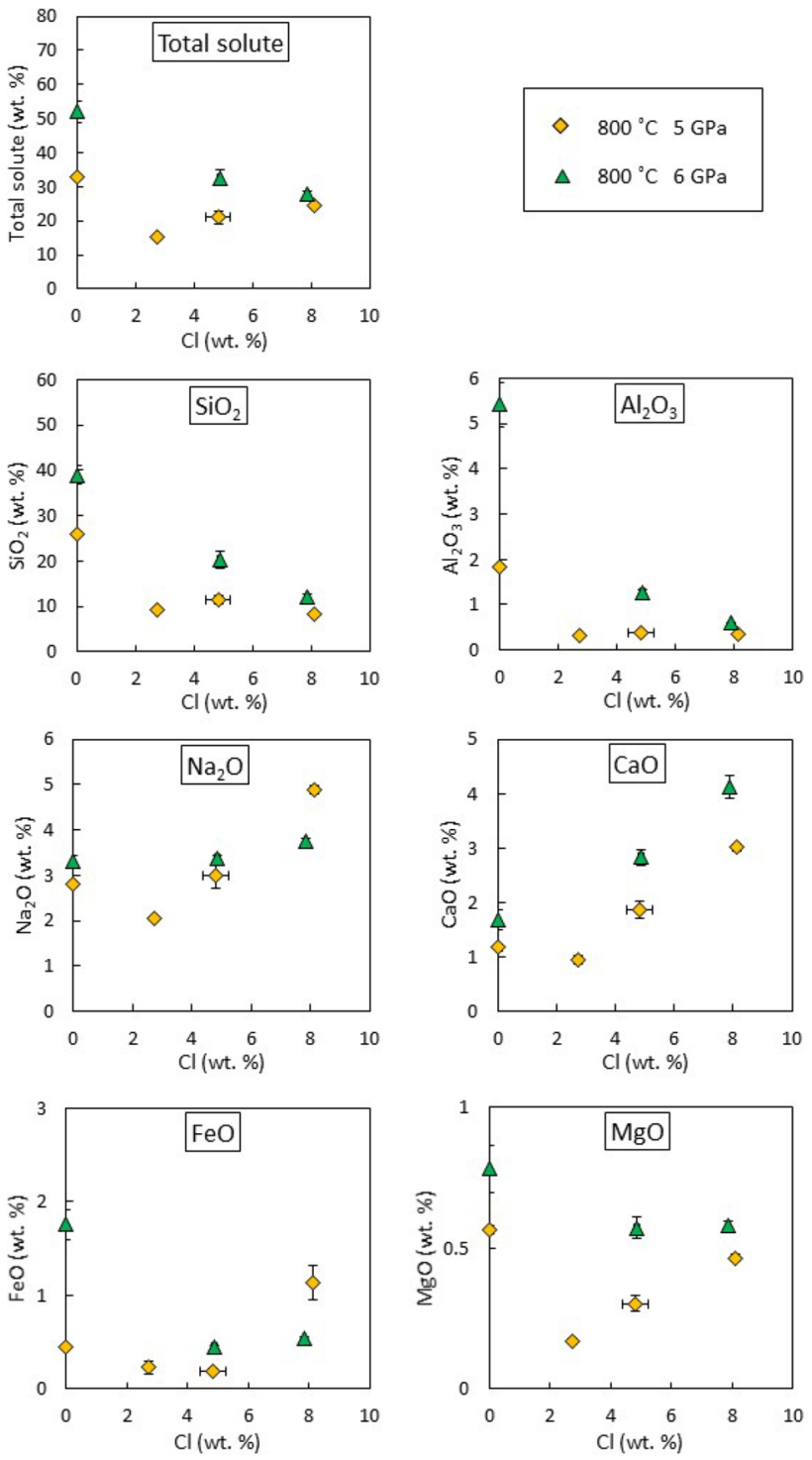

Fig. 2 Bulk composition of saline fluids in equilibrium with an eclogitic assemblage from high-pressure experiments at 5 and $6 \mathrm{GPa}$ and $800{ }^{\circ} \mathrm{C}$. "Total solute" is the sum of all oxide components plus $\mathrm{Cl}$, with a slight negative correction for the fact that $1 \mathrm{Cl}^{-}$replaces $1 / 2 \mathrm{O}^{2-}$ in the fluid

$\mathrm{GPa}$. While $\mathrm{CaO}$ increases with $\mathrm{Cl}$ at all pressures, the effect diminishes for $\mathrm{Na}_{2} \mathrm{O}, \mathrm{FeO}$ and $\mathrm{MgO}$ at $5 \mathrm{GPa}$ and nearly disappears or reverts at $6 \mathrm{GPa}$. Very likely, these effects are due to the high bulk $\mathrm{SiO}_{2}$ contents of $\mathrm{Cl}$-free fluids at 5 and particularly at $6 \mathrm{GPa}$, where the fluids may be considered to approaching a "supercritical" state, intermediate in composition between typical aqueous fluids and silicate melts. At these high $\mathrm{SiO}_{2}$ contents, cations may dissolve mostly as neutral silicate species or silicate complexes. Upon addition of $\mathrm{Cl}$, silicate anions compete with $\mathrm{Cl}^{-}$for cations, such that the effect of $\mathrm{Cl}$ on oxide solubilities becomes less pronounced. The negative effect 
of $\mathrm{Cl}$ on $\mathrm{SiO}_{2}$ solubilities is consistent with previous observations by Cruz and Manning (2015) in the quartz$\mathrm{H}_{2} \mathrm{O}-\mathrm{NaCl}$ system at $1.5-2 \mathrm{GPa}$, and higher temperatures.

As demonstrated by Rustioni et al. (2021), solubilities in aqueous fluids measured with the diamond trap method yield results accurate within a factor of two. While this has a minor effect in the determination of trace element partition coefficients, which may vary by orders of magnitude, this factor may be significant for major element contents and it may explain the significant scatter in some of the data reported in Figs. 1 and 2.

\section{Trace element partition coefficients}

As already observed by Rustioni et al. (2019), fluid/eclogite partition coefficients are highly affected by fluid salinity at $4 \mathrm{GPa}$ and $800{ }^{\circ} \mathrm{C}$. In particular, light rare earths (LREE) show an increase in solubility of up to three orders of magnitude with an addition of $7 \mathrm{wt} \%$ of $\mathrm{Cl}$. A significant, even though smaller, solubility enhancement is observed also for LILE, as well as for $\mathrm{Pb}$, Th and $\mathrm{U}$. On the other hand, fluid salinity does not have a significant effect on the partitioning behavior of HFSE. Similar results were found also in experiments conducted at a lower temperature $\left(700{ }^{\circ} \mathrm{C}\right)$ and higher pressure ( 5 and $6 \mathrm{GPa}$ ). Results from these experiments are shown in Figs. 3 and 4 in comparison to the data
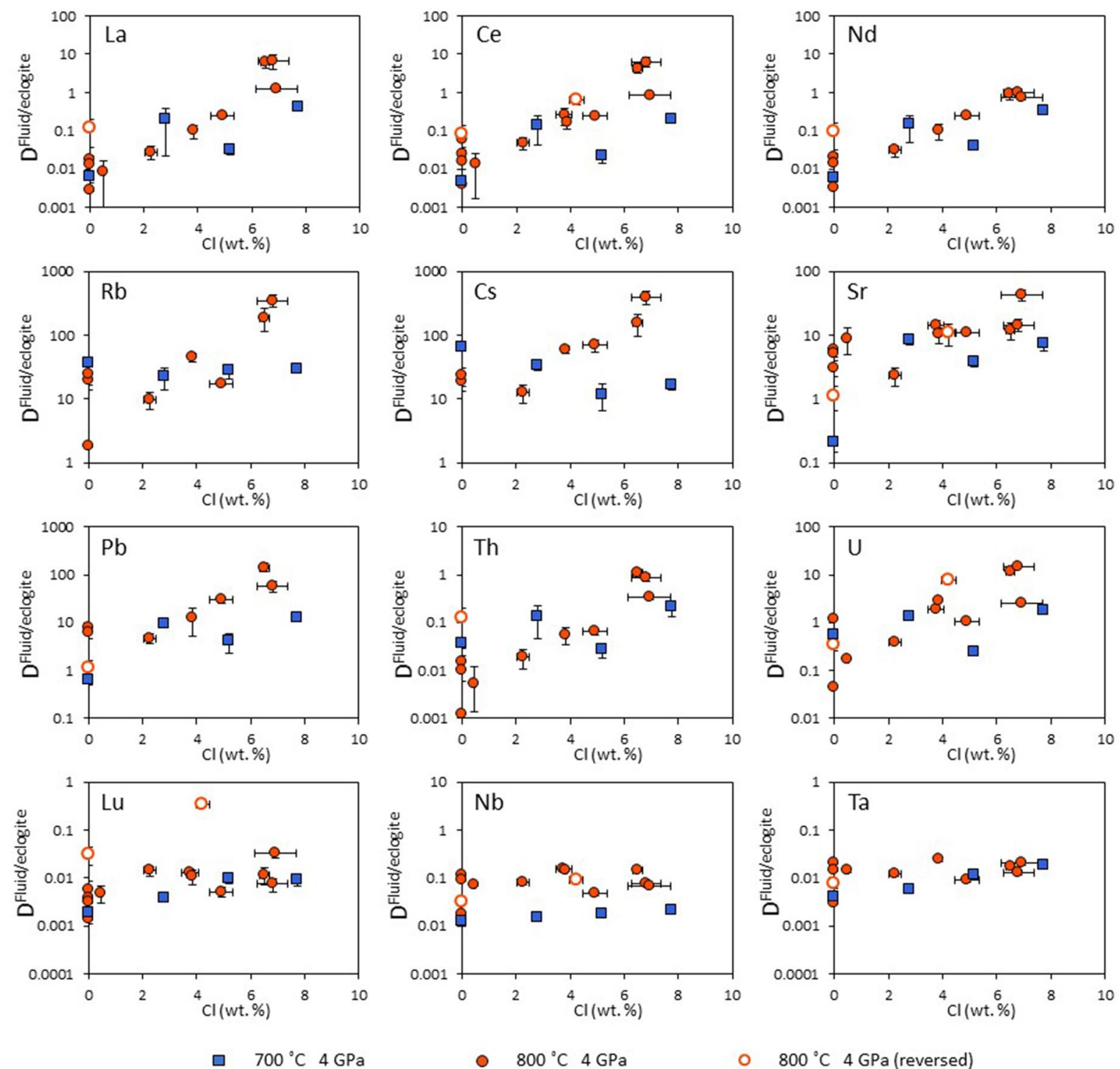

- $800{ }^{\circ} \mathrm{C} \quad 4 \mathrm{GPa}$

- $800^{\circ} \mathrm{C} \quad 4 \mathrm{GPa}$ (reversed)

Fig. 3 Influence of fluid salinity on the fluid/eclogite partition coefficient of trace elements at $4 \mathrm{GPa}$ and $700-800{ }^{\circ} \mathrm{C}$ 

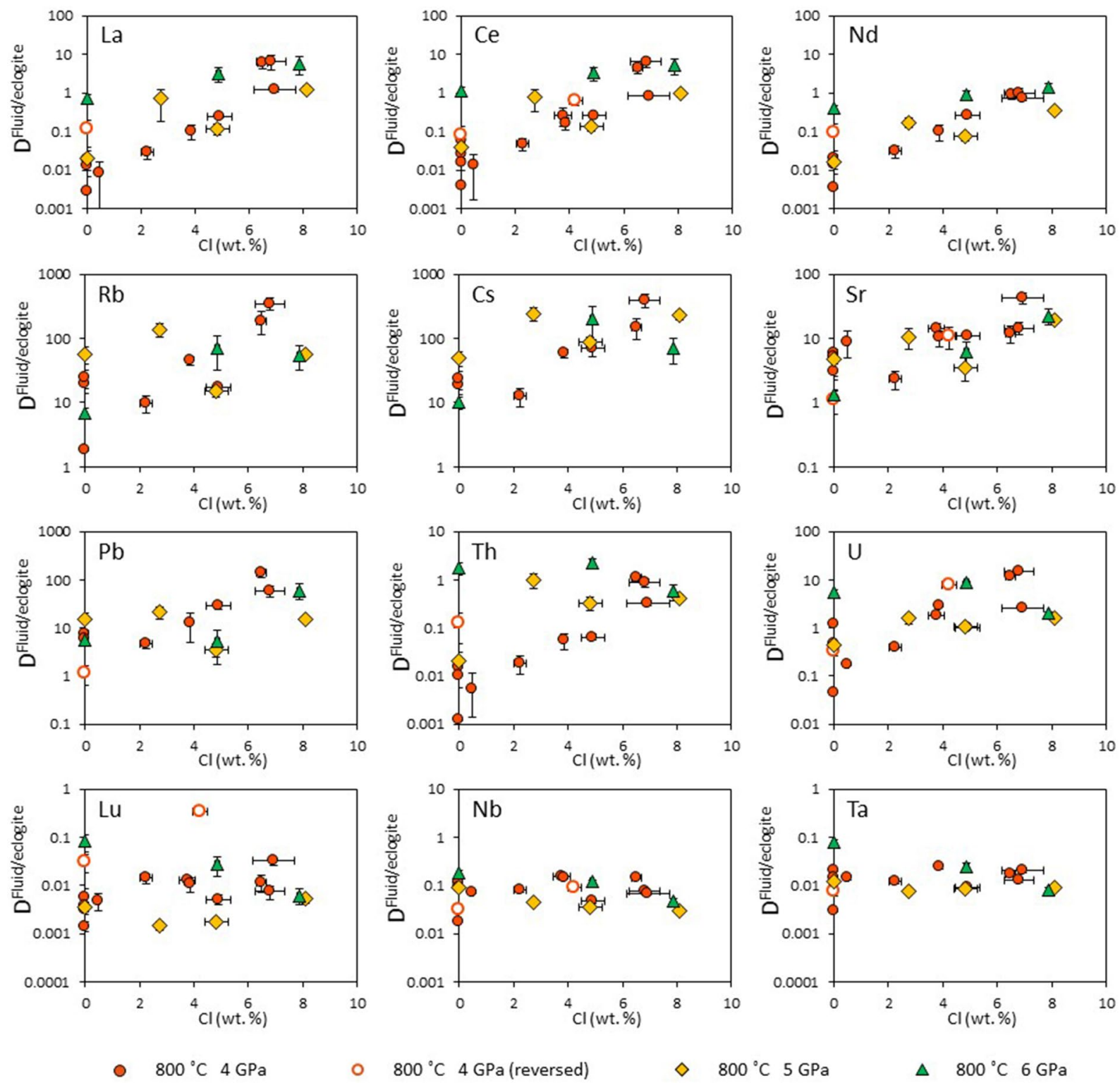

$800^{\circ} \mathrm{C} \quad 4 \mathrm{GPa}$ (reversed)

$\diamond \quad 800^{\circ} \mathrm{C} 5 \mathrm{GPa}$

$\triangle 800^{\circ} \mathrm{C} \quad 6 \mathrm{GPa}$

Fig. 4 Influence of fluid salinity on the fluid/eclogite partition coefficient of trace elements at 5-6 GPa and $800{ }^{\circ} \mathrm{C}$

from Rustioni et al. (2019). Complete analytical data are compiled in Tables S-3 to S-7 in the supplementary online material. The strong enhancement of the fluid/eclogite partitioning of the light rare earth elements by $\mathrm{Cl}$ is seen at all $\mathrm{P}$, $\mathrm{T}$ conditions, while the HREE, as well as $\mathrm{Nb}$ and $\mathrm{Ta}$, are never affected by salinity.

A detailed inspection of the data shows that at $4 \mathrm{GPa}$, the temperature has only a minor effect on the fluid/eclogite partitioning of trace elements (Fig. 3). The partition coefficients measured at $700{ }^{\circ} \mathrm{C}$ tend to be slightly lower than at $800{ }^{\circ} \mathrm{C}$, but the dependence on fluid salinity is similar. Notable exceptions are $\mathrm{Rb}$ and $\mathrm{Cs}$, where the $700{ }^{\circ} \mathrm{C}$ data appear to be nearly independent of fluid salinity; very likely, this may be an artifact due to incomplete equilibration at the lower temperature. $D_{\mathrm{Nb}}$ fluid/eclogite increases by one order of magnitude with temperature increasing from 700 to $800{ }^{\circ} \mathrm{C}$. A pressure increase from 4 to 5 or $6 \mathrm{GPa}$ does not fundamentally alter the partition coefficients and their dependence on salinity for most elements. However, notable exceptions from this are Th and $\mathrm{U}$; for both elements, the partitioning into the fluid at low salinity is strongly enhanced by pressure, in agreement with previous observations by Kessel et al. (2005). Potentially, the interaction with silicate species due to the greatly enhanced $\mathrm{SiO}_{2}$ solubility in the fluid (see above) is responsible for this effect. A similar, but weaker enhancement of fluid/eclogite partitioning with pressure at low salinity is also observed for $\mathrm{La}$ and $\mathrm{Ce}$. 
Different eclogite modal compositions may also cause changes in the bulk fluid/eclogite partition coefficients. The individual fluid/mineral partition coefficients $D^{\text {fluid/mineral }}$ for garnet and omphacite and the effect of fluid salinity on those are shown in Fig. 5. Garnet retains lower trace element concentrations than omphacite, with the exception of the heavy rare earth elements. Therefore, increasing the modal abundance of garnet relative to omphacite generally enhances $D^{\text {fluid/eclogite }}$, except for the HREE.

As rutile is able to retain a large amount of HFSE, but none of the other investigated trace elements, the presence of rutile, even in small proportions, only affects the partitioning behavior of $\mathrm{Nb}$, $\mathrm{Ta}$, and $\mathrm{Ti}$, leaving the remaining trace element pattern essentially unchanged. Figure 6 shows the $D^{\text {fluid/eclogite }}$ calculated without and with 1 or $2 \%$ of rutile in the eclogite. These results show that the presence of rutile strongly depletes the fluid in $\mathrm{Nb}$ and $\mathrm{Ta}$, especially at high salinities. This effect is similar for the addition of 1 or $2 \%$ rutile, implying that already small proportions of this mineral can greatly affect the $D^{\text {fluid/eclogite }}$ for $\mathrm{Nb}$ and Ta. Still, a depletion in these elements relative to the light rare earths is never observed for pure water, even with rutile in the eclogitic assemblage. For high salinities, on the other hand, a slight negative anomaly in $\mathrm{Nb}$ and $\mathrm{Ta}$ is already produced even in the absence of rutile.

\section{Discussion}

\section{Comparison with previous studies}

As noted by Rustioni et al. (2019), the fluid/eclogite partition coefficients of trace elements measured in this study for pure water (without $\mathrm{NaCl}$ ) are generally in very good agreement with those obtained by Kessel et al. (2005) using similar methods. However, there is an apparent discrepancy between this study and some previous publications, which suggested that complexing by $\mathrm{Cl}$ does not significantly enhance the fluid/mineral partitioning of trace elements in aqueous fluids under typical subduction zone conditions. Brenan et al. (1995) observed only a minor enhancement of the fluid/clinopyroxene partition coefficients of $\mathrm{Sr}$ and $\mathrm{Pb}$ upon addition of $\mathrm{NaCl}$ at $900{ }^{\circ} \mathrm{C}$ and 2 $\mathrm{GPa}$. However, the $\mathrm{NaCl}$ concentrations used in that study were rather low, 0.5 molal, which corresponds to just 1.77 $\mathrm{wt} \% \mathrm{Cl}$. This concentration is small compared to the concentration range investigated in the present study and it is also at the low end of fluid salinities inferred from the $\mathrm{Cl}$ / $\mathrm{H}_{2} \mathrm{O}$ ratio of primitive arc basalts (Métrich and Wallace 2008). If $\mathrm{Sr}^{2+}$ or $\mathrm{Pb}^{2+}$ dissolved in the fluid as undissociated $\mathrm{SrCl}_{2}$ or $\mathrm{PbCl}_{2}$, one would expect an increase of the
Fig. 5 Fluid/garnet (a) and fluid/clinopyroxene (b) partition coefficients of various trace elements at $4 \mathrm{GPa}$ and $800{ }^{\circ} \mathrm{C}$
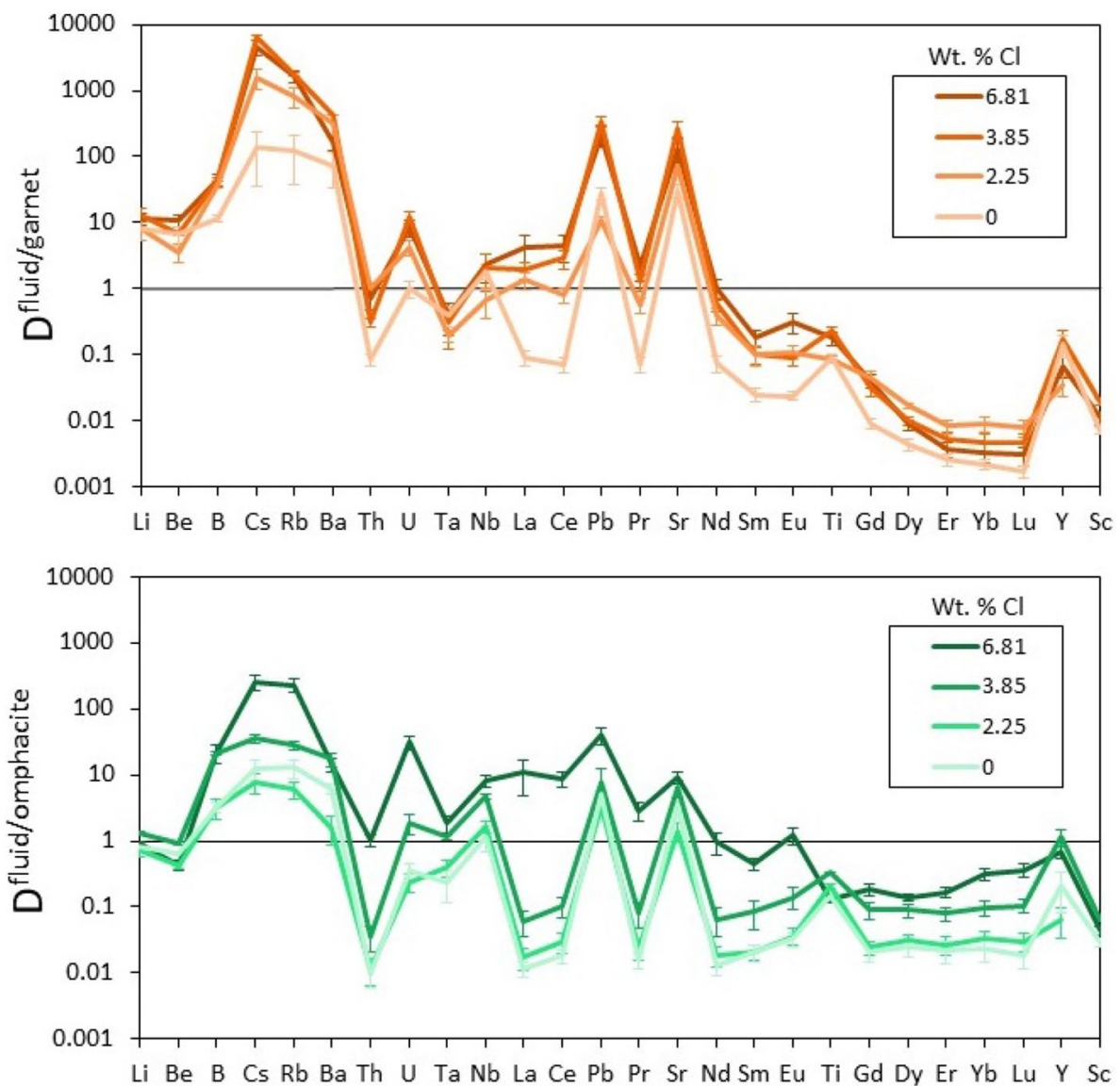

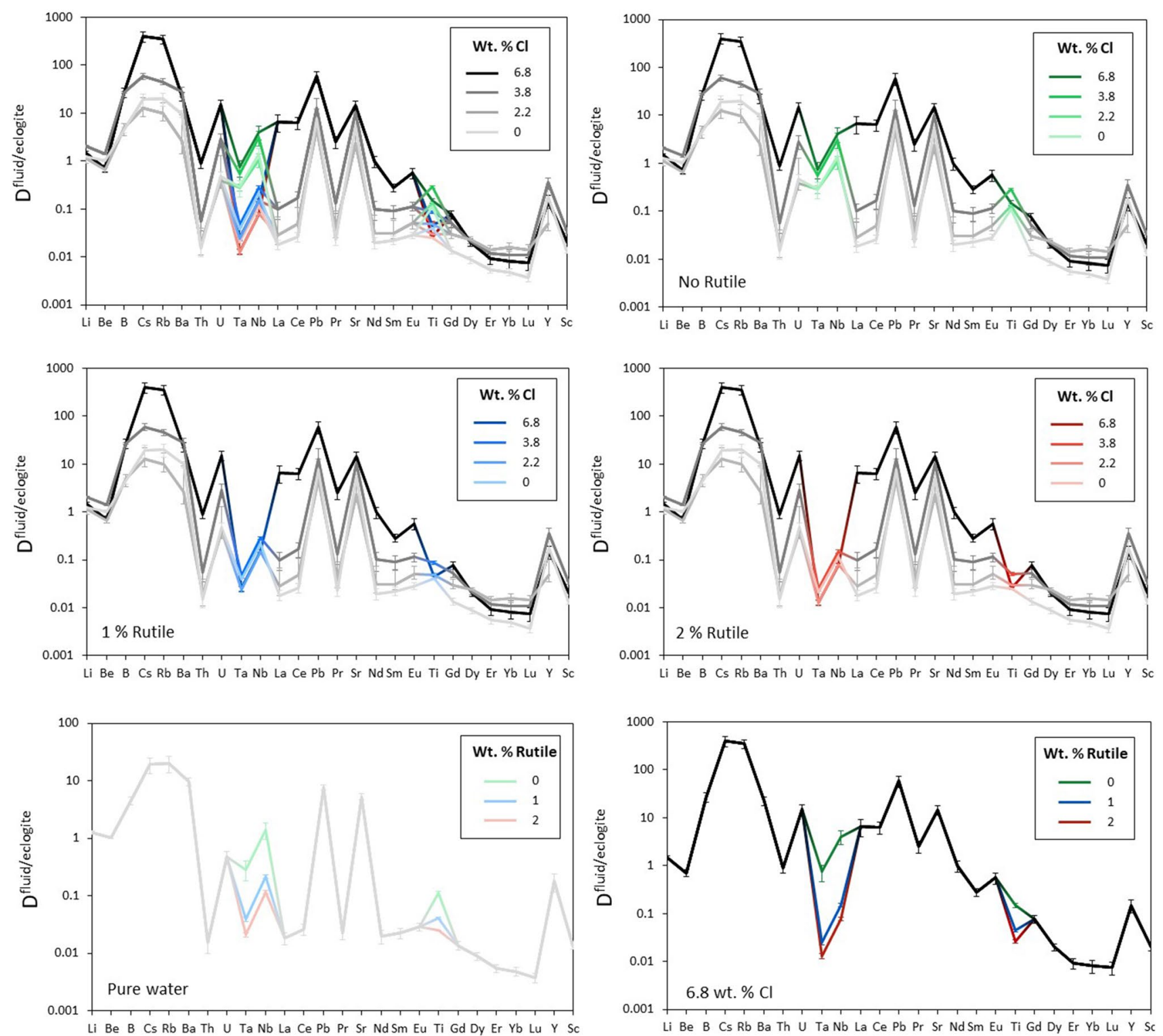

Fig. 6 Bulk fluid/eclogite partition coefficients of trace elements at $4 \mathrm{GPa}$ and $800{ }^{\circ} \mathrm{C}$ with different rutile contents in the eclogite and for variable fluid salinities. The diagram in the upper left corner summarizes the results from the other diagrams

$\mathrm{SrCl}_{2}$ and $\mathrm{PbCl}_{2}$ activity in the fluid with the square of the $\mathrm{Cl}^{-}$activity. Necessarily, this would imply that low salinities have little effect on the fluid/mineral partitioning of these elements. Stalder et al. (1998) claimed that adding up to $5 \mathrm{~m} \mathrm{HCl}$ has "nearly no effect" on the fluid/ garnet partition coefficient of a large suite of trace elements at $1000{ }^{\circ} \mathrm{C}$ and $4-5 \mathrm{GPa}$. However, they carried out only two experiments with $\mathrm{Cl}$-bearing fluids. Moreover, there is only one single pair of experiments under otherwise equal conditions, where only the $\mathrm{HCl}$ content of the fluid varied. If one compares their experiments no. 57 and $64, D_{\mathrm{Ba}}{ }^{\text {fluid/garnet }}$ increased from 16 to 59 and $D_{\mathrm{Sr}}$ fluid/ garnet increased from 13 to 31 upon addition of $1.5 \mathrm{M} \mathrm{HCl}$.
Only $D_{\mathrm{Pb}}{ }^{\text {fluid/garnet }}$ appeared to decrease. Moreover, we note that many of the partition coefficients reported by Stalder et al. (1998) are in striking contrast to more recent experimental data obtained with improved experimental methods. For example, their data would suggest that $\mathrm{Nb}$ always partitions strongly in favor of the fluid in equilibrium with clinopyroxene or garnet, even more so than $\mathrm{Sr}$, while both the data of Kessel et al. (2005) and of Rustioni et al. (2019) suggest much lower fluid/mineral partition coefficients for $\mathrm{Nb}$.

Support for the enhancement of fluid/mineral partition coefficients by $\mathrm{Cl}^{-}$complexing under subduction zone conditions comes from a number of recent studies. Both 
Tsay et al. (2014) and Tropper et al. (2011) observed major increases in the solubilities of $\mathrm{La}_{2} \mathrm{Si}_{2} \mathrm{O}_{7}$ and $\mathrm{CePO}_{4}$, respectively in aqueous fluids at $1-2.6 \mathrm{GPa}$ and $600-800{ }^{\circ} \mathrm{C}$ upon addition of Cl. Bali et al. (2011) observed similar effects for $\mathrm{UO}_{2}$ solubility in aqueous fluids at 1.5-2.6 GPa. Kawamoto et al. (2014) studied the fluid/melt partitioning of $\mathrm{Pb}$, $\mathrm{Rb}$, and $\mathrm{Sr}$ by direct in-situ synchrotron fluorescence in the hydrothermal diamond anvil cell to $1.3 \mathrm{GPa}$ and $830{ }^{\circ} \mathrm{C}$ and observed a strong enhancement of the partitioning of these elements into the fluid with increasing $\mathrm{Cl}$ concentration. On the other hand, Tsay et al. (2017) studied the fluid/eclogite partitioning of a large suite of trace elements at $590-800{ }^{\circ} \mathrm{C}$ and 2.4-2.6 GPa and did not observe enhanced fluid/eclogite partitioning of trace elements upon the addition of $\mathrm{NaCl}$. This result is rather curious, as it appears to contradict the study of Tsay et al. (2014) from the same group, which found a major enhancement of the solubility of the LREE in aqueous fluids upon addition of $\mathrm{NaCl}$. Possibly, the data reported by Tsay et al. (2017) involve incomplete equilibration between the eclogite and the fluid, perhaps due to early formation and closure of the fluid inclusions used to trap the fluid. While they used some in-situ fracturing method to control the time of inclusion formation, it is not implausible that some fluid inclusions may already have formed rather early during the run, such that the fluid trapped was not in equilibrium with the eclogite.

\section{A numerical model for the trace element signature of primitive arc basalts}

To better constrain the mechanism of magma generation in subduction zones, we use our data to quantitatively model the trace element composition of partial melts from a mantle wedge metasomatized by saline fluids released from the basaltic part of the subducted slab. We will then compare these data with the worldwide compilation of primitive arc basalt compositions from Kelemen et al. (2005). For modeling the composition of the fluids released from the slab, we use our fluid/eclogite partitioning data obtained at $4 \mathrm{GPa}$ and $800{ }^{\circ} \mathrm{C}$. These conditions fall right in the middle of the subduction zone thermal profiles as compiled by Syracuse et al. (2010). We argue that they are plausible for an eclogite just after the dehydration of amphibole, which is expected to be the major carrier of water in the basaltic part of the slab. The experimental study of Schmidt and Poli (1998) places the high-pressure stability limit of amphibole near $2.4 \mathrm{GPa}$. These experiments were, however, carried out with $5 \mathrm{wt} \%$ water added to the system. Mandler and Grove (2016) pointed out that the apparent stability limit of amphibole in mantle peridotite strongly depends on the amount of water added to the charge in experiments. This is because alkalis-which are required to form amphibole-strongly partition into the fluid. High fluid fractions in the charge, therefore, destabilize amphibole. Mandler and Grove (2016) showed that for water contents $<1 \mathrm{wt} \%$, the high-pressure stability limit of amphibole approaches $4 \mathrm{GPa}$. While these data were obtained for a peridotitic bulk composition, a similar effect likely also occurs in basaltic systems, implying that the high-pressure stability limit of amphibole may well be $1 \mathrm{GPa}$ higher than inferred by Schmidt and Poli (1998). Therefore, our experimental data for $4 \mathrm{GPa}$ and $800{ }^{\circ} \mathrm{C}$ may capture the conditions during or just after amphibole dehydration.

The experimental data on the fluid/eclogite partitioning of trace elements in this study and in Rustioni et al. (2019) were obtained with a starting material free of $\mathrm{K}$ and $\mathrm{P}$, very similar to that used in the previous study of Kessel et al. (2005). This is justified, as both $\mathrm{K}\left(0.160 \mathrm{wt} \% \mathrm{~K}_{2} \mathrm{O}\right)$ and $\mathrm{P}\left(0.184 \mathrm{wt} \% \mathrm{P}_{2} \mathrm{O}_{5}\right)$ are only trace constituents in MORB (Gale et al. 2013). As pointed out by Rustioni et al. (2019), the high phosphorus solubility in garnet (Konzett and Frost 2009) implies that in an eclogite of MORB composition, separate phosphate phases such as apatite are unlikely to be stable. For similar reasons, phengite is expected to be either completely absent or present only in trace amounts. This is supported by an experimental study of Carter et al. (2015) who did not observe any apatite or phengite in an eclogite produced at $3 \mathrm{GPa}$ and $800{ }^{\circ} \mathrm{C}$ from a natural MORB starting material. Hermann (2002) suggested that allanite may be an important phase retaining LREE and Th in subducted eclogites. However, in an experimental study of a natural MORB composition up to $2.8 \mathrm{GPa}$, Sisson and Kelemen (2018) could not detect any allanite or any other epidote group mineral above $750{ }^{\circ} \mathrm{C}$. We are therefore confident that our fluid/eclogite partitioning data, which are based on an eclogite with omphacite + garnet + rutile mineralogy can be directly used to model trace element transport from the basaltic part of the subducted slab to the mantle wedge.

In our model, we assume that the composition of the basaltic part of the subducted slab corresponds to the "all MORB" average from Gale et al. (2013) and the peridotite in the mantle wedge above the slab has the composition of the depleted mantle as estimated by Salters and Stracke (2004). For predicting the partitioning of trace elements between aqueous fluids and eclogite, we used the equation

$D^{\text {fluid/eclogite }}=a e^{b C l}$

where $D^{\text {fluid/eclogite }}$ is the fluid/eclogite partition coefficient of the element considered and $\mathrm{Cl}$ is fluid salinity in $\mathrm{wt} \% \mathrm{Cl}$; $a$ and $b$ are regression coefficients calibrated by our experimental data and tabulated for each element in Table 1. The concentration of a trace element in fluid $c_{\text {fluid }}$ in equilibrium with the MORB eclogite was then calculated assuming batch equilibrium partitioning using the equation 
Table 1 Regression coefficients for the dependence of the fluid/eclogite partitioning coefficient of trace elements at $4 \mathrm{GPa}$ and $800{ }^{\circ} \mathrm{C}$ on fluid salinity

\begin{tabular}{lrlrl}
\hline & $a$ & $b$ & \multicolumn{1}{l}{$X^{2}$} & $R^{2}$ \\
\hline $\mathrm{Li}$ & $0.355 \pm 0.215$ & $0.346 \pm 0.151$ & 6.12 & 0.972 \\
$\mathrm{Be}$ & $1.021 \pm 0.176$ & $0.003 \pm 0.045$ & 13.14 & 0.001 \\
$\mathrm{~B}$ & $3.514 \pm 1.009$ & $0.379 \pm 0.065$ & 1.09 & 0.991 \\
$\mathrm{Rb}$ & $3.003 \pm 2.243$ & $0.669 \pm 0.184$ & 3.08 & 0.935 \\
$\mathrm{Cs}$ & $10.202 \pm 4.586$ & $0.470 \pm 0.103$ & 1.42 & 0.952 \\
$\mathrm{Sr}$ & $2.408 \pm 0.804$ & $0.368 \pm 0.083$ & 2.39 & 0.928 \\
$\mathrm{Ba}$ & $4.339 \pm 2.570$ & $0.347 \pm 0.142$ & 3.66 & 0.852 \\
$\mathrm{Ti}$ & $0.007 \pm 0.002$ & $0.223 \pm 0.109$ & 276.04 & 0.048 \\
$\mathrm{Nb}$ & $0.018 \pm 0.001$ & $0.233 \pm 0.056$ & 91.81 & 0.337 \\
$\mathrm{Ta}$ & $0.003 \pm 0.006$ & $0.239 \pm 0.065$ & 36.10 & 0.354 \\
$\mathrm{La}$ & $0.005 \pm 0.002$ & $0.961 \pm 0.118$ & 0.96 & 0.976 \\
$\mathrm{Ce}$ & $0.010 \pm 0.004$ & $0.855 \pm 0.106$ & 1.10 & 0.968 \\
$\mathrm{Nd}$ & $0.008 \pm 0.003$ & $0.714 \pm 0.076$ & 0.70 & 0.984 \\
$\mathrm{Sm}$ & $0.010 \pm 0.004$ & $0.588 \pm 0.088$ & 1.55 & 0.985 \\
$\mathrm{Eu}$ & $0.017 \pm 0.005$ & $0.572 \pm 0.070$ & 1.15 & 0.981 \\
$\mathrm{Gd}$ & $0.005 \pm 0.001$ & $0.462 \pm 0.053$ & 14.89 & 0.565 \\
$\mathrm{Dy}$ & $0.005 \pm 0.002$ & $0.456 \pm 0.134$ & 4.34 & 0.920 \\
$\mathrm{Er}$ & $0.003 \pm 0.001$ & $0.171 \pm 0.079$ & 12.19 & 0.214 \\
$\mathrm{Yb}$ & $0.003 \pm 0.009$ & $0.204 \pm 0.077$ & 9.47 & 0.292 \\
$\mathrm{Lu}$ & $0.002 \pm 0.008$ & $0.235 \pm 0.085$ & 9.19 & 0.265 \\
$\mathrm{Y}$ & $0.035 \pm 0.013$ & $0.387 \pm 0.091$ & 2.81 & 0.901 \\
$\mathrm{Sc}$ & $0.013 \pm 0.004$ & $0.056 \pm 0.075$ & 18.48 & 0.123 \\
$\mathrm{~Pb}$ & $2.428 \pm 1.137$ & $0.565 \pm 0.117$ & 1.75 & 0.939 \\
$\mathrm{Th}$ & $0.003 \pm 0.002$ & $0.809 \pm 0.117$ & 1.30 & 0.971 \\
$\mathrm{U}$ & $0.109 \pm 0.061$ & $0.727 \pm 0.135$ & 2.13 & 0.949 \\
\hline
\end{tabular}

Data were fitted to Eq. (1) $D^{\text {fluid/eclogite }}=a e^{b \mathrm{Cl}}$

For some elements, $R^{2}$ is below 0.9 ; these are typically elements with fluid/eclogite partition coefficients that are nearly independent of $\mathrm{Cl}$, such that Eq. (1) does not describe the partition behavior well and the scatter in the data may be larger than the variability due to $\mathrm{Cl}$

$c_{\text {fluid }}=\frac{D^{\text {fluid/eclogite }} c_{\mathrm{MORB}}}{1+x_{\text {fluid }}\left(D^{\text {fluid/eclogite }}-1\right)}$

where $x_{\text {fluid }}$ is the mass fraction of the fluid in the subducted eclogite and $c_{\mathrm{MORB}}$ is the concentration of the trace element in the MORB eclogite according to Gale et al. (2013).

The composition of the metasomatized peridotite in the zone of melting in the mantle wedge was then calculated according to

$c_{\text {source }}=x_{\text {fluid }} c_{\text {fluid }}+\left(1-x_{\text {fluid }}\right) c_{\text {peridotite }}$

where $c_{\text {source }}$ is the trace element concentration in the source, $x_{\text {fluid }}$ is the mass fraction of fluid added and $c_{\text {peridotite }}$ is the concentration in the depleted mantle according to Salters and Stracke (2004).

The composition of partial melts from the metasomatized mantle source was then obtained from the following equation, which assumes batch melting:

$c_{\text {melt }}=\frac{c_{\text {source }} / D^{\text {peridotite/basalt }}}{1+x_{\text {melt }}\left(1 / D^{\text {peridotite/basalt }}-1\right)}$

where $c_{\text {melt }}$ is the concentration of some trace elements in the partial melt, $x_{\text {melt }}$ is the mass fraction of melt and $D^{\text {peridotite/basalt }}$ is the bulk partition coefficient of the trace element between peridotite and melt. $D^{\text {peridotite/basalt }}$ was calculated from individual mineral/melt partition coefficients for a mantle peridotite with $60 \mathrm{wt} \%$ olivine, $30 \mathrm{wt} \%$ orthopyroxene, $5 \mathrm{wt} \%$ garnet, and $5 \mathrm{wt} \%$ clinopyroxene coexisting with the partial melt. Mineral/basalt partition coefficients for REE, $\mathrm{Ba}, \mathrm{U}, \mathrm{Th}, \mathrm{Pb}, \mathrm{Y}$, and $\mathrm{Nb}$ were taken as averages of the experimental data reported in Salters et al. (2002). Clinopyroxene/basalt and garnet/basalt partition coefficients for $\mathrm{Rb}$ were taken from Klemme et al. (2002), for $\mathrm{Sr}$ from Johnson (1994). The partitioning of $\mathrm{Sr}$ and $\mathrm{Rb}$ into olivine and orthopyroxene was assumed to be zero. Titanium $\left(\mathrm{Ti}^{4+}\right)$ partition coefficients were taken from Mallmann and O'Neill (2009) and from Johnson (1994). In general, since the trace elements considered here are mostly incompatible in peridotite, variations in the values of the mineral/melt partition coefficients have a rather minor effect on the final result of the calculation. For this reason, possible variations due to the presence of water in the melt (e.g. Sun and Liang 2012) were also ignored. In a recent study, Meltzer and Kessel (2020) observed that water significantly affects the partitioning of REE between garnet and melts, but only at rather high water contents (molar fraction of $\mathrm{H}_{2} \mathrm{O}>0.5$ ) such that this effect is probably not relevant here.

The results of the calculations outlined above depend on four independent parameters: (i) the fluid salinity, (ii) the fluid fraction in the eclogite, (iii) the fluid fraction added to the source of melting, and (iv) the degree of melting in the mantle wedge. Of these four variables, the fluid salinity is by far the most important parameter, since the fluid/eclogite partition coefficient of some trace elements increases exponentially with salinity, while others are nearly independent of salinity. Fluid salinity therefore does not only produce the strongest absolute variations in final melt composition, but it also changes the fractionation of the various trace elements relative to each other. In contrast to this, the other three parameters-fluid fraction in eclogite, fluid fraction added to the source, and degree of melting in the mantle wedge have some influence on the absolute level of trace element enrichment in the final melt, but they induce only minor variations in the fractionation of trace elements relative to each other. 
For fluid salinity, we explored a parameter space up to 10 $\mathrm{wt} \% \mathrm{Cl}$ in the fluid, which would be equivalent to about 16 wt $\%$ of $\mathrm{NaCl}$. This is well within the range of fluid salinities inferred from the $\mathrm{Cl} / \mathrm{H}_{2} \mathrm{O}$ ratio in primitive arc basalts (Métrich and Wallace 2008). Experimentally, we have calibrated partition coefficients to about $7 \mathrm{wt} \% \mathrm{Cl}$ in the fluid, such that only a minor extrapolation is involved in our modeling. For the fluid fraction in the eclogite, we consider values between 1 and $2 \mathrm{wt} \%$ most plausible, considering that amphibole itself contains only about $2 \mathrm{wt} \%$ water. Higher fluid fractions would likely require some external source (e.g. serpentine dehydration of the hydrated mantle below the basaltic layer). While such an external addition of water is possible, it is also likely that at some distance from the source the fluid flow becomes channelized (e.g. Zack and John 2007; John et al. 2012; Plümper et al. 2017), such that only a small fraction of the basaltic layer might be affected. Therefore, in our calculations, we mostly assumed a fluid fraction in the eclogite layer of $2 \mathrm{wt} \%$. Reducing this to $1 \mathrm{wt} \%$ has only a minor effect on the final trace element enrichment pattern. Essentially, at the lower fluid fraction, the abundances of the most fluid-mobile elements ( $\mathrm{Ba}, \mathrm{Sr}$, $\mathrm{Rb}, \mathrm{Pb}$ ) increase slightly in the final melt composition, while the other elements are hardly affected. This is because at a low fluid fraction, for most elements the concentration in the fluid approaches $D^{\text {fluid/eclogite. }} c_{\mathrm{MORB}}$, i.e. it is nearly independent of fluid fraction. Only for the elements with very high $D^{\text {fluid/eclogite }}$, already at low fluid fraction the reservoir becomes strongly depleted in these elements and the aforementioned approximation cannot be used anymore; the concentration in the fluid will then decrease with increasing fluid fraction. For the fluid fraction added to the source, we consider values from 2.5 to $10 \mathrm{wt} \%$. Plausible values for the degree of melting in the mantle wedge are probably between 10 and 30\% (e.g. Schmidt and Jagoutz 2017). This parameter has the smallest effect on the final melt composition and therefore, for most calculations, we assumed it to be around $20 \%$.

In the supplementary online material, we provide a "Subduction Calculator" as Excel spreadsheet, which allows a rapid assessment of expected melt composition according to the model outlined above. Calculations with a model fluid released from the basaltic part of the subducted slab at $6 \mathrm{GPa}$ are also possible. The regression coefficients for the fluid/ eclogite trace element partitioning at $6 \mathrm{GPa}$ are compiled in Table 2. However, $6 \mathrm{GPa}$ is beyond most of the dehydration reactions expected in a subducted slab and a modelbased solely on a fluid composition produced at such high pressures is not very plausible. The following discussion is therefore mostly based on the data at $4 \mathrm{GPa}$ and $800{ }^{\circ} \mathrm{C}$.

Figure 7 shows arc magma compositions predicted by our model, assuming $2.5 \mathrm{wt} \%, 5 \mathrm{wt} \%$, or $10 \mathrm{wt} \%$ fluid addition to the source of melting in the mantle wedge, with fluid
Table 2 Regression coefficients for the dependence of the fluid/eclogite partitioning coefficient of trace elements at $6 \mathrm{GPa}$ and $800{ }^{\circ} \mathrm{C}$ on fluid salinity

\begin{tabular}{|c|c|c|c|c|}
\hline & $a$ & $b$ & $X^{2}$ & $R^{2}$ \\
\hline $\mathrm{Li}$ & $2.449 \pm 1.781$ & $-0.008 \pm 0.100$ & 28.68 & 0.004 \\
\hline $\mathrm{Be}$ & $1.630 \pm 0.372$ & $-0.103 \pm 0.038$ & 2.84 & 0.845 \\
\hline B & $9.451 \pm 1.392$ & $0.137 \pm 0.024$ & 0.38 & 0.973 \\
\hline $\mathrm{Rb}$ & $7.056 \pm 1.517$ & $0.269 \pm 0.063$ & 1.38 & 0.807 \\
\hline Cs & $10.227 \pm 3.660$ & $0.252 \pm 0.093$ & 2.58 & 0.654 \\
\hline $\mathrm{Sr}$ & $1.285 \pm 0.114$ & $0.356 \pm 0.021$ & 0.23 & 0.982 \\
\hline $\mathrm{Ba}$ & $2.431 \pm 0.518$ & $0.483 \pm 0.065$ & 1.37 & 0.866 \\
\hline $\mathrm{Ti}$ & $0.209 \pm 0.018$ & $-0.114 \pm 0.019$ & 0.35 & 0.972 \\
\hline $\mathrm{Nb}$ & $0.986 \pm 0.140$ & $-0.115 \pm 0.027$ & 0.22 & 0.937 \\
\hline $\mathrm{Ta}$ & $0.378 \pm 0.039$ & $-0.205 \pm 0.019$ & 0.09 & 0.985 \\
\hline $\mathrm{La}$ & $0.740 \pm 0.072$ & $0.274 \pm 0.024$ & 0.14 & 0.978 \\
\hline $\mathrm{Ce}$ & $1.146 \pm 0.066$ & $0.197 \pm 0.015$ & 0.07 & 0.987 \\
\hline $\mathrm{Nd}$ & $0.396 \pm 0.020$ & $0.163 \pm 0.010$ & 0.06 & 0.995 \\
\hline $\mathrm{Sm}$ & $0.268 \pm 0.002$ & $0.044 \pm 0.001$ & 0.01 & 0.999 \\
\hline $\mathrm{Eu}$ & $0.359 \pm 0.057$ & $0.021 \pm 0.035$ & 0.90 & 0.261 \\
\hline Gd & $0.136 \pm 0.016$ & $-0.017 \pm 0.025$ & 0.39 & 0.292 \\
\hline Dy & $0.098 \pm 0.021$ & $-0.158 \pm 0.009$ & 0.04 & 0.995 \\
\hline $\mathrm{Er}$ & $0.108 \pm 0.005$ & $-0.273 \pm 0.037$ & 0.47 & 0.953 \\
\hline $\mathrm{Yb}$ & $0.099 \pm 0.030$ & $-0.329 \pm 0.050$ & 0.74 & 0.922 \\
\hline $\mathrm{Lu}$ & $0.088 \pm 0.026$ & $-0.328 \pm 0.051$ & 0.66 & 0.837 \\
\hline $\mathrm{Y}$ & $1.583 \pm 1.194$ & $-0.463 \pm 0.120$ & 0.99 & 0.734 \\
\hline $\mathrm{Sc}$ & $0.069 \pm 0.034$ & $-0.224 \pm 0.077$ & 3.15 & 0.783 \\
\hline $\mathrm{Pb}$ & $5.354 \pm 2.312$ & $0.081 \pm 0.224$ & 5.67 & 0.069 \\
\hline Th & $2.216 \pm 1.326$ & $-0.123 \pm 0.112$ & 8.79 & 0.467 \\
\hline $\mathrm{U}$ & $5.956 \pm 3.554$ & $-0.121 \pm 0.110$ & 6.35 & 0.499 \\
\hline
\end{tabular}

For explanation, see Table 1

salinities ranging from 0 to $10 \mathrm{wt} \% \mathrm{Cl}$. The model result for Pr in this diagram is not directly calculated, but interpolated between $\mathrm{Ce}$ and $\mathrm{Nd}$. The data are shown in comparison to a global compilation of average primitive arc magma compositions from Kelemen et al. (2005). This compilation includes data from the Kermadec, Lesser Antilles, Marianas, New Hebrides, Scotia, Tonga, Aleutian, Andean, Cascades, Central America, and Kamchatka arcs. The model data clearly show that metasomatism by a pure aqueous fluid cannot account for the trace element enrichment in arc magmas, as this would only produce minor enrichments of the most fluid-mobile elements $\mathrm{Rb}, \mathrm{Ba}, \mathrm{Sr}$, and $\mathrm{Pb}$. This result is consistent with the frequent view that aqueous fluids are "too dilute" to produce the enrichment seen in arc magmas (e.g. Hermann et al. 2006; Spandler and Pirard 2013). However, the situation changes once saline fluids are considered. Already a fluid with $5 \mathrm{wt} \% \mathrm{Cl}$ produces an enrichment of $\mathrm{Rb}, \mathrm{Ba}, \mathrm{U}, \mathrm{Pb}$, and $\mathrm{Sr}$ that similar to that observed in many arc basalts. Only the light REE (La and $\mathrm{Ce}$ ) and in particular Th require higher fluid salinities to match the enrichment 

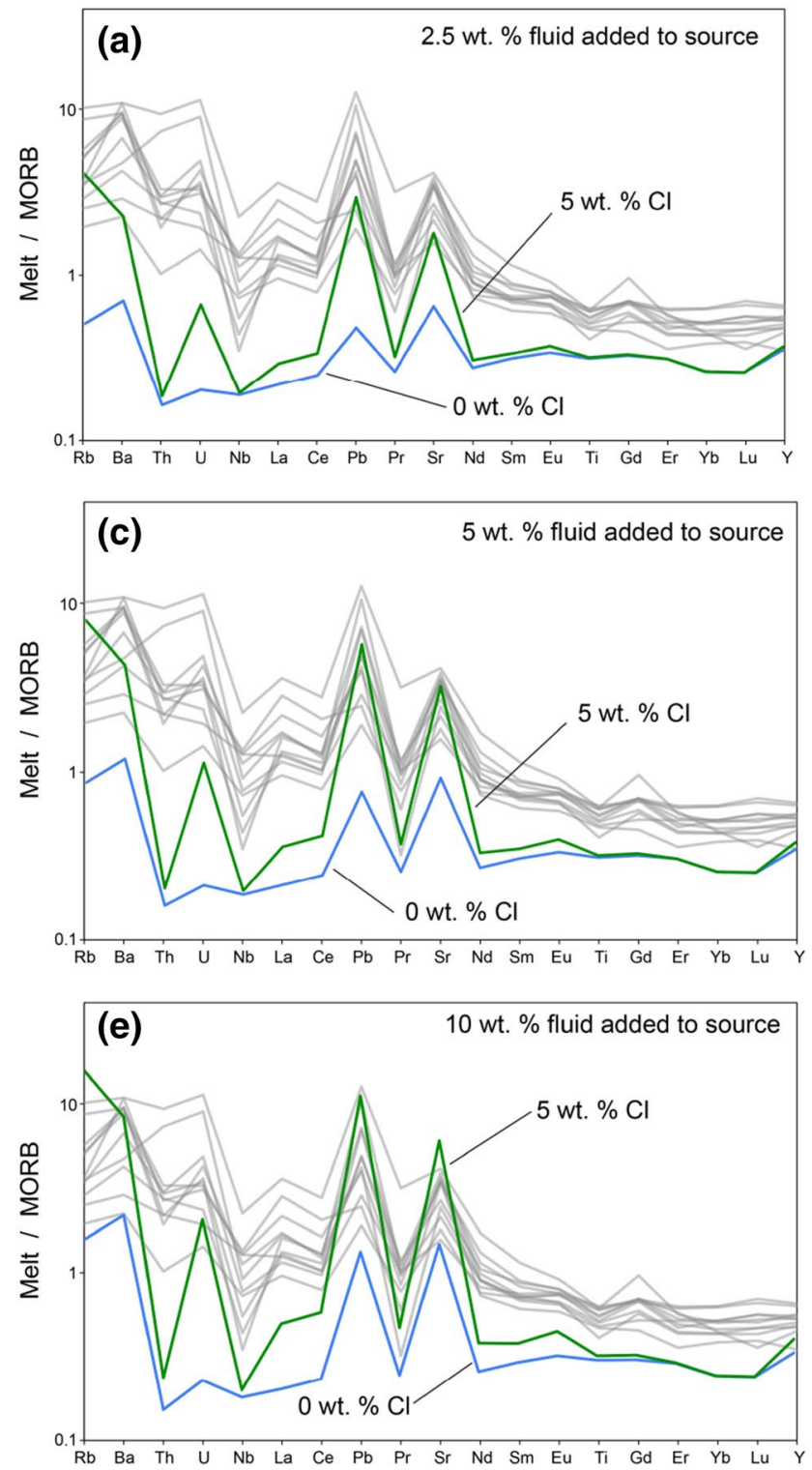

Fig. 7 Predicted trace element enrichment patterns for partial melts of the mantle wedge enriched by aqueous fluids from the basaltic layer of the subducted slab. Compositions for primitive arc basalts as compiled by Kelemen et al. (2005) are shown as grey lines for comparison. All data were normalized to the "all MORB average"

observed in natural magmas. The enrichment of $\mathrm{La}$ and $\mathrm{Ce}$ are well reproduced by salinities between 7 and $10 \mathrm{wt} \% \mathrm{Cl}$. For $\mathrm{Th}$, the highest salinities near $10 \mathrm{wt} \% \mathrm{Cl}$ yield values overlapping with primitive arc basalt compositions. Therefore, the modeling results are shown in Fig. 7 show very clearly that virtually the entire trace element enrichment pattern observed in primitive arc basalts can be reproduced by melting a depleted mantle source metasomatized by saline fluids. For salinities between 7 and $10 \mathrm{wt} \% \mathrm{Cl}$, already 2.5 wt $\%$ fluid addition to the source of melting is sufficient to match most of the arc basalt patterns. High salinities above
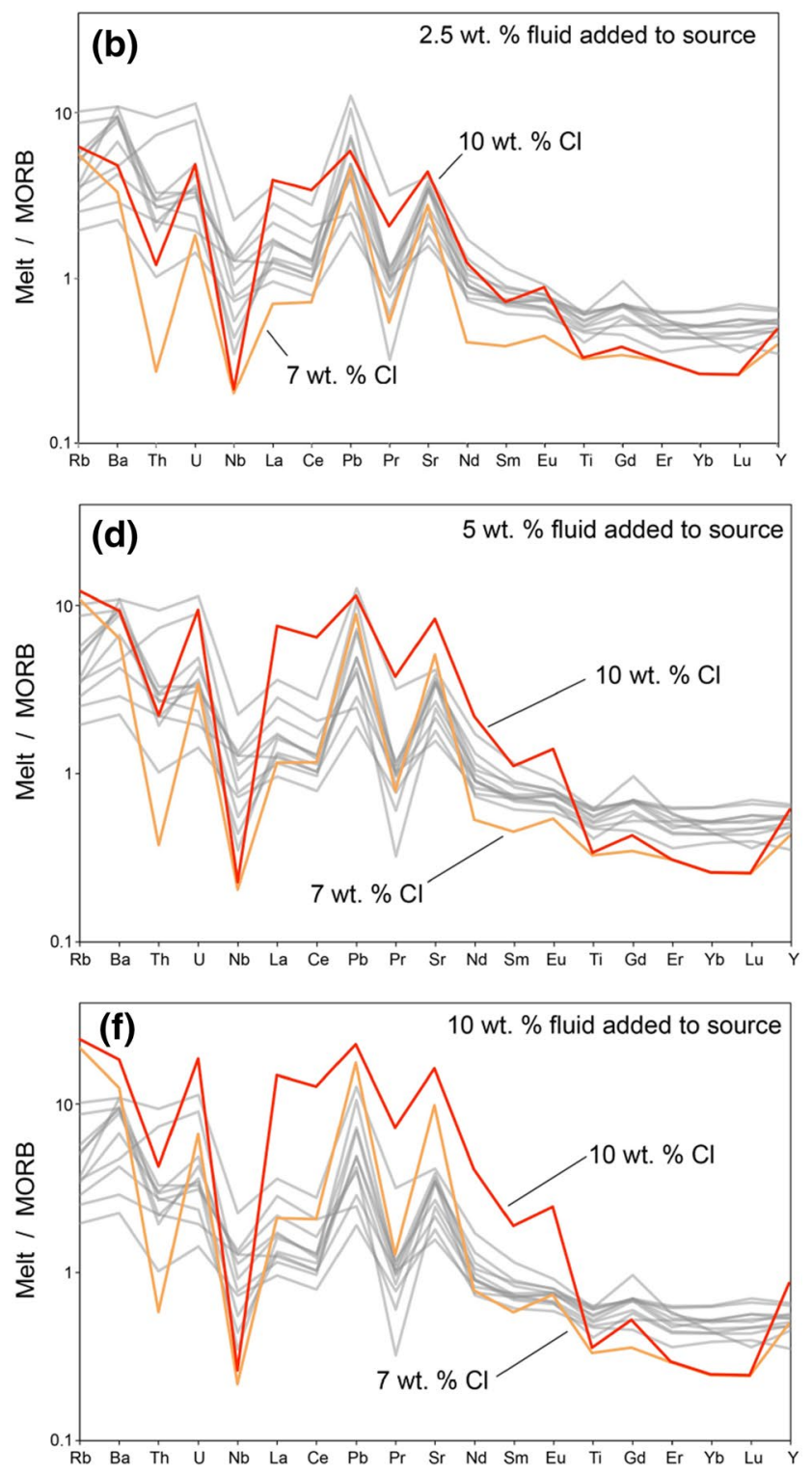

of Gale et al. (2013). Model calculations are shown for 2.5-10 wt $\%$ fluid addition to the source and for fluid salinities from 0 to $10 \mathrm{wt} \%$ Cl. The model result for Pr is not directly calculated, but interpolated between $\mathrm{Ce}$ and $\mathrm{Nd}$

$7 \mathrm{wt} \% \mathrm{Cl}$ are particularly important to match the natural thorium abundances.

When discussing Th abundances, it is important to note that the data point for Th in a plot as in Fig. 7 depends very much on the choice of the MORB composition used for standardization. Here, for consistency, we use the "all MORB average" of $0.404 \mathrm{ppm}$ Th from Gale et al. (2013) for standardization, which was also used for calculating the composition of fluids released from the slab. However, this number is more than two times higher than the often-used N-type MORB abundance of 0.1871 ppm Th from Hofmann 
(1988). Even the "all normal MORB average" from Gale et al. (2013) is with $0.353 \mathrm{ppm}$ Th still about twice the value quoted by Hofmann (1988). The rather high enrichment of Th in arc magmas suggested by some MORB-normalized diagrams is therefore partially an artifact of normalization to a likely less-representative Th abundance in MORB. Nevertheless, the enrichment of Th in some of the primitive arc basalts would require metasomatism by a very Cl-rich fluid released from the slab at $4 \mathrm{GPa}$ and $800{ }^{\circ} \mathrm{C}$. There is, however, an obvious alternative possibility. Pearce et al. (2005) noted in a study of the Mariana arc that the $\mathrm{Th} / \mathrm{Ba}$ ratio in magmas very much increases with the depth of the slab and they, therefore, attributed the Th addition mainly to a "deep subduction component". Indeed, in the study of Kessel et al. (2005) in a Cl-free system, increasing the pressure from 4 to $6 \mathrm{GPa}$ at a constant temperature of $800{ }^{\circ} \mathrm{C}$ increased the partitioning of Th into the fluid by about one order of magnitude, while the effect on Ba was more subtle. Our data (Fig. 4) show a similar enhancement of thorium partitioning into the fluid with pressure for low-salinity fluids. It is therefore entirely plausible that the relatively high Th abundances in some primitive arc basalts may reflect the influence of an additional fluid component released from the slab at higher pressures. Another, perhaps less likely explanation could be that the Th enrichment is due to an additional complexing agent in the fluid, such as fluoride. Fluoride complexing is known to enhance Th mobility at lower pressures (Keppler and Wyllie 1990) and the recent study of Tsay et al. (2017) showed such an effect also under mantle conditions. However, as noted above, we suspect that the latter study suffered from some incomplete attainment of equilibrium. Moreover, the $\mathrm{F}$ abundance in arc magmas is typically one order of magnitude below the $\mathrm{Cl}$ abundance (Straub and Layne 2003), which also makes a significant effect of $\mathrm{F}^{-}$complexing on trace element enrichment in arc magmas rather unlikely, although not completely impossible.

A general observation from Fig. 7 is that our models produce a negative $\mathrm{Nb}$ anomaly (and by inference $\mathrm{Nb} \mathrm{Ta}$ anomaly) that is more pronounced than in most arc basalts. This is, however, the result of assuming $2 \mathrm{wt} \%$ of rutile in the residual eclogite. Reducing the rutile fraction would diminish the magnitude of the negative $\mathrm{Nb} \mathrm{Ta}$ anomaly. In fact, the data shown in Fig. 6 suggest that such an anomaly could also be produced by saline fluid without any rutile in the eclogite residue. The comparison of our modeling results with the observed arc basalt patterns in Fig. 7, therefore, suggests that the fraction of rutile in the eclogite that released the metasomatizing fluid must be rather small.

\section{Possible limitations of the model}

While the model outlined above is very successful in reproducing the trace element pattern of arc magmas, it contains a number of simplifications. The fluid released from the basaltic part of the slab almost certainly does not have a constant composition. Rather, upon decomposition of amphibole or other hydrous minerals, $\mathrm{Cl}$ very likely strongly partitions into the fluid, although there are no experimental data that would allow quantification of this effect. Therefore, the very first fluid released from the slab likely has high salinity, which then decreases upon further dehydration. Accordingly, one would expect that the trace element enrichment pattern of a real arc magma is a somehow weighed average of the curves for different salinities shown in Fig. 7. Since, however, the fluid/eclogite partition coefficient of many trace elements increases exponentially with salinity, this means that the first aliquot of highly saline fluids contributes a disproportionally high fraction of the trace elements. Therefore, while the curves shown in Fig. 7 may suggest that the trace element enrichment in arc magmas requires very high salinities, the average salinity of the fluids added to the source may actually be considerably lower. This effect nicely reconciles the fluid salinities required for the trace element enrichment with those inferred from primitive melt inclusions from arc basalts, which range mostly from 5 to $15 \mathrm{wt} \%$ $\mathrm{NaCl}$ equivalent (Métrich and Wallace 2008).

Another important effect that is not directly considered in our model is the modification of fluid composition by interaction with the nominally anhydrous minerals of the mantle peridotite during percolation to the zone of melting. According to Mierdel et al. (2007), at temperatures of $800-900{ }^{\circ} \mathrm{C}$ as they are expected in the mantle just above the slab surface, orthopyroxene may dissolve up to $0.5 \mathrm{wt} \%$ water. Any aqueous fluid percolating through this part of the mantle wedge will therefore likely lose water and become more concentrated. While this process will not affect the delivery of the incompatible trace elements to the mantle wedge, it is important to understand the water budget of the entire process. The models shown in Fig. 7 involve 2.5-10 wt\% fluid addition to the source of melting. Assuming that this fluid contained 60-70 wt $\%$ water and the water is completely incompatible during melting, this would mean that for $20 \%$ partial melting, the magma generated contains 8-32 wt $\%$ of water. While the lower bound of this estimate is entirely realistic for primitive arc basalts (Métrich and Wallace 2008; Goltz et al. 2020), the upper bound is clearly out of the range of water contents observed in nature. However, if some of the water originally present in the fluid has been lost due to interaction with the mantle peridotite before it reaches the zone of melting, this problem disappears. During the "desiccation" of the fluid, the flux of trace elements transported likely would not change, as they are mostly highly incompatible in mantle minerals, as is $\mathrm{Cl}$ (Bernini et al. 2013). The excess solute in the fluid, which is mainly $\mathrm{SiO}_{2}$, would probably react with olivine to form some orthopyroxene during the percolation process. Evidence for such "desiccated" 
subduction zone fluids is preserved in highly concentrated, Cl-rich inclusions in diamonds with exceptionally high concentrations of incompatible trace elements (Weiss et al. 2015; Klein-BenDavid et al. 2007).

\section{The possible role of sediment melts in arc magmatism}

To address the question whether hydrous slab fluids or sediment melts are the essential triggers for arc magmatism, we also calculated the trace element composition of magma produced by partial melting of a mantle source enriched by a few percent of sediment melts. The melt compositions for temperatures that are realistic for a slab surface were taken from the experimental studies of Hermann and Rubatto (2009), Skora and Blundy (2010) and Skora et al. (2015). Hermann and Rubatto (2009) experimentally studied a sediment composition close to GLOSS (global subducting sediment, Plank and Langmuir 1988). However, in their experimental starting material, some trace elements were doped at much higher concentration levels than in GLOSS. Therefore, in order to make their experimental results compatible with natural starting material compositions, we multiplied their experimentally derived trace element concentrations in partial melts by a correction factor $f_{X}=$ (concentration of $X$ in GLOSS)/(concentration of $X$ in experimental starting material). A similar correction factor, relative to natural radiolarian clay composition, was applied to the data from the melting experiments from synthetic radiolarian clay by Skora and Blundy (2010). On the other hand, no correction was applied to the experimental results of Skora et al. (2015) on natural calcareous clay or marl.

Aside from the compositions of the sediment melts, the assumptions of the model are identical to that described
Fig. 8 Predicted trace element enrichment patterns for partial melts of the mantle wedge enriched by $5 \mathrm{wt} \%$ of sediment melts. Near-solidus melt compositions were taken from the experimental studies of Hermann and Rubatto (2009) for GLOSS (global subducting sediment), Skora and Blundy (2010) for radiolarian clay and Skora et al. (2015) for calcareous sediment and marl. Compositions for primitive arc basalts as compiled by Kelemen et al. (2005) are shown for comparison as grey lines. All data were normalized to the "all MORB average" of Gale et al. (2013). A few of the rare earth data have been interpolated between neighboring rare earths
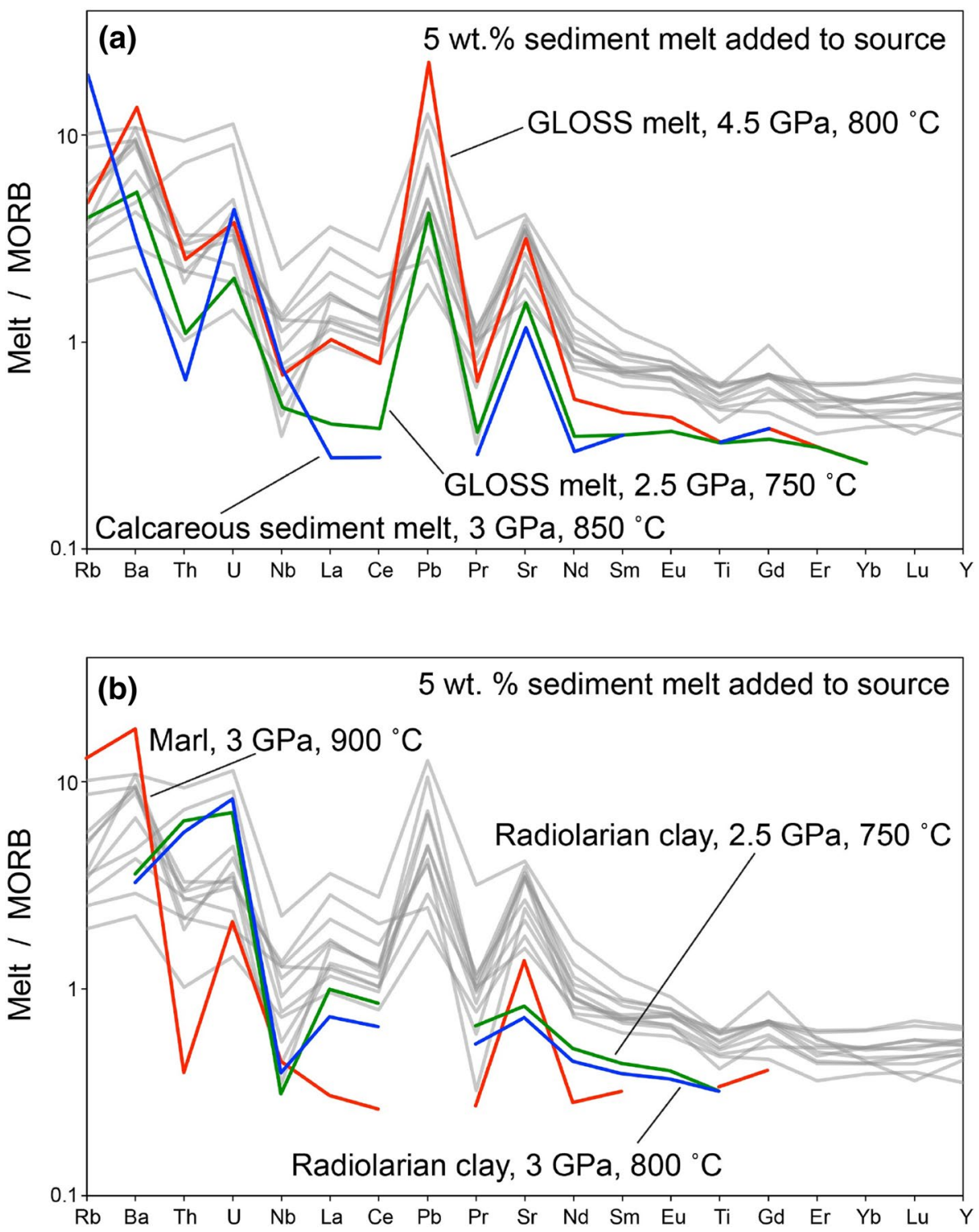
above for fluid metasomatism, i.e. the initial depleted mantle composition is from Salters et al. (2002), the peridotite/ basalt partition coefficients are the same as above and a degree of melting of $20 \%$ in the mantle source as assumed. Figure 8 shows the results of this calculation. Obviously, the addition of sediment melt to the magma source has only limited success in producing a trace element enrichment pattern that resembles a typical arc basalt. None of the sediment melts produces the required enrichment of the LREE $\mathrm{La}$ and $\mathrm{Ce}$. Moreover, several of the sediment melts yield an incorrect fractionation of $\mathrm{Nb}$ relative to the LREE. The GLOSS melts give little fractionation and the calcareous clay or marl melts would even produce an enrichment of $\mathrm{Nb}$ relative to $\mathrm{La}$ and $\mathrm{Ce}$. Most of the partial melts-with the exception of GLOSS at $4.5 \mathrm{GPa}$ and $800^{\circ} \mathrm{C}$-have difficulties to enrich $\mathrm{Sr}$ to the required level. Overall, the GLOSS melt is most successful in producing an arc-like pattern. The reason for this, however, is very simple: The bulk composition of GLOSS is similar to the average upper continental crust as already noted by Plank and Langmuir (1988). Since the upper continental crust is mostly produced by magmatism in subduction zones, GLOSS has essentially inherited a subduction-like trace-element enrichment pattern. This pattern can, however, not have formed in the first place if it requires the addition of a sediment component, which already contains the required enrichment pattern. In contrast to this, our preferred model of the addition of a saline fluid from a subducted MORB eclogite to the zone of melting in the mantle wedge produces a typical arc-basalt pattern de novo, without requiring any other pre-enrichment process.

Another interesting observation from Fig. 8 is that for Th, but also for some other elements, the enrichment pattern produced by different sediment melts is very different. While carbonate melts do not enrich Th at all, partial melts from radiolarian clay are very efficient in doing so. This is a rather curious result, as high Th enrichments were often considered to be some kind of fingerprint of sediment melts (e.g. Elliott et al. 1997; Class et al. 2000). As our experimental results (Figs. 3 and 4) and models (Fig. 7) show, a strong Th enrichment may well be produced by high-salinity fluids or generally aqueous fluids released above $4 \mathrm{GPa}$. The strong differences in the enrichment pattern caused by different sediment melts (Fig. 8) would suggest that if sediment melts contributed strongly to trace element enrichment, it should be easy to distinguish arc basalts produced in subduction zones with mostly carbonate subduction from those with mostly pelite subduction or no sediment subduction. However, this is not so. The compilation of primitive arc basalt composition shown as background in Figs. 7 and 8 includes data from arcs with little or no sediment subduction (e.g. Kamchatka) as well as arcs with massive sediment subduction. Also, the composition of the sediment subducted changes, from mostly pelites (e.g. Tonga) in some arcs to mostly carbonates (e.g. Central America) in other arcs. Nevertheless, the enrichment pattern of trace elements in the different arcs is overall remarkably similar.

\section{The cause of melting in subduction zones}

Based on the comparison of the modeling results shown in Figs. 7 and 8, we conclude that the sediment melt contribution to primitive arc basalts is negligible and that these magmas are essentially produced by melting of a mantle source enriched by hydrous saline fluids released from the basaltic part of the subducted slab. Our results do not rule out some sediment melt contribution to other types of magmas found in subduction zones; in particular, for ultrapotassic melts, such a contribution is plausible (e.g. Mallik et al. 2015). However, numerous geochemical arguments for a sediment contribution to the generation of arc magmas, such as the correlation of trace element (e.g. Th/La) and isotope ratios of magmas and subducted sediments (e.g. Armstrong 1971; Turner and Foden 2001; Plank 2005) do not necessarily involve sediment melting. The experimental data presented here for a basaltic eclogitic system make it rather plausible that saline fluids could transport incompatible trace elements, including Th from the sediments to the source of melting. This process could also transport $\mathrm{Pb}$, $\mathrm{Sr}$, and $\mathrm{Nd}$ isotopic signals. While this hypothesis requires additional experimental testing with sediment lithologies, a recent study by Ferrando et al. (2019) provides direct observational support for this mechanism. They studied aqueous fluid inclusions from subducted kyanite-bearing quartzites from Sulu (China) and observed strong enrichments of $\mathrm{Rb}$, $\mathrm{Ba}, \mathrm{Sr}, \mathrm{Pb}, \mathrm{U}, \mathrm{Th}$, and the LREE in the fluid. We, therefore, suggest that in particular isotopic "sediment signals" are often transported by saline aqueous fluids. Moreover, as noted above, some elemental enrichments, particularly of Th that have often been attributed to sediment melts (e.g. Elliott et al. 1997; Class et al. 2000) can be produced by saline fluids released from the basaltic part of the subducted slab alone, without any sediment involvement. We therefore suggest that the importance of sediment melting for the generation of arc magmas has been greatly overestimated and in reality, this contribution may be rather limited.

\section{Conclusions}

(1) Chloride strongly enhances the fluid/eclogite partitioning of alkalis, alkaline earths, light rare earth elements, of $\mathrm{U}$, Th, and of $\mathrm{Pb}$. This effect is likely due to the formation of ion pairs or undissociated $\mathrm{Cl}^{-}$complexes in the fluid. Typical HFSE, such as $\mathrm{Ti}, \mathrm{Nb}$, or $\mathrm{Ta}$, on the 
other hand, do not partition significantly into the fluid, even at high fluid salinities.

(2) We demonstrate that the entire trace element abundance pattern of primitive arc basalts can be reproduced by adding a few percent of saline fluid (with 5-10 wt $\% \mathrm{Cl}$ ) released from the basaltic part of the subducted slab to the zone of melting below the arc. Only for Th, possibly some minor contribution from a silica-rich aqueous fluid released at greater depth may be required as an additional component to match the observed enrichment pattern in some cases.

(3) Rutile is the only accessory phase in the residual eclogite that has an important effect on the trace element abundance pattern in arc basalts by selectively retaining HFSE. We note, however, that saline fluids would generate a negative $\mathrm{Nb}$ and $\mathrm{Ta}$ anomaly even in the absence of rutile. Other accessory phases, such as apatite, phengite, or allanite are likely unimportant, because they are either unstable in a MORB eclogite at the relevant $\mathrm{P}, \mathrm{T}$ conditions or they occur only in trace amounts.

(4) Metasomatism by sediment melts alone is unable to produce the enrichment pattern seen in arc basalts. Sediment melts generated at plausible slab-surface temperatures do not produce the required enrichment of LREE. Moreover, they often fail to produce the proper fractionation between $\mathrm{Nb}$ and the LREE.

(5) Similarities in the enrichment pattern produced by sediment melts to that seen in arc magmas primarily result from the fact that the sediments themselves have inherited a trace element abundance pattern that resembles the continental crust. This pattern likely had been formed by previous episodes of melting in subduction zones. Any model that invokes sediment melts as the primary driver of arc magmatism therefore could never explain how the typical trace element signature of arc magmas evolved in the first place.

(6) At least for primitive arc basalts, magma formation, and trace element enrichment are caused by the release of aqueous fluid from the basaltic part of the subducted slab. The involvement of sediment melts in this process is negligible. It is still possible that sediment melts contribute to the formation of other subduction-related magmas, e.g. ultrapotassic melts. In general, however, we suggest that the importance of sediment melts for magma generation in subduction zones has been overestimated.

Supplementary Information The online version contains supplementary material available at https://doi.org/10.1007/s00410-021-01810-8.

Acknowledgements This study was supported by the DFG (Deutsche Forschungsgemeinschaft) International Research Training Group “Deep Earth Volatile Cycles", DFG GRK 2156/1. Constructive reviews by Dante Canil and by two anonymous referees helped to improve the manuscript.

Funding Open Access funding enabled and organized by Projekt DEAL.

Open Access This article is licensed under a Creative Commons Attribution 4.0 International License, which permits use, sharing, adaptation, distribution and reproduction in any medium or format, as long as you give appropriate credit to the original author(s) and the source, provide a link to the Creative Commons licence, and indicate if changes were made. The images or other third party material in this article are included in the article's Creative Commons licence, unless indicated otherwise in a credit line to the material. If material is not included in the article's Creative Commons licence and your intended use is not permitted by statutory regulation or exceeds the permitted use, you will need to obtain permission directly from the copyright holder. To view a copy of this licence, visit http://creativecommons.org/licenses/by/4.0/.

\section{References}

Arculus RJ, Powell R (1986) Source component mixing in the regions of arc magma generation. J Geophys Res 91:5913-5926

Armstrong RL (1971) Isotopic and chemical constraints on models of magma genesis in volcanic arcs. Earth Planet Sci Lett 12:37-142

Bali E, Audetat A, Keppler H (2011) The mobility of U and Th in subduction zone fluids: an indicator of oxygen fugacity and fluid salinity. Contrib Mineral Petrol 161:597-613

Bali E, Keppler H, Audetat A (2012) The mobility of W and Mo in subduction zone fluids and the Mo-W-Th-U systematics of island arc magmas. Earth Planet Sci Lett 351:195-207

Barnes JD, Manning CE, Scambelluri M, Selverstone J (2018) The behavior of halogens during subduction-zone processes. In: Harlov DE, Aranovich L (eds) The role of halogens in terrestrial and extraterrestrial geochemical processes. Springer, pp 545-590

Behn MD, Kelemen PB, Hirth G, Hacker BR, Massonne HJ (2011) Diapirs as the source of the sediment signature in arc lavas. Nat Geosci 4:641-646

Bénard A, Klimm K, Woodland AB, Arculus RJ, Wilke M, Botcharnikov RE, Shimizu N, Nebel O, Rivard C, Ionov DA (2018) Oxidising agents in sub-arc mantle melts link slab devolatilisation and arc magmas. Nature Comm 9:3500

Bernini D, Wiedenbeck M, Dolejs D, Keppler H (2013) Partitioning of halogens between mantle minerals and aqueous fluids: implications for the fluid flow regime in subduction zones. Contrib Mineral Petrol 165:117-128

Brenan JM, Shaw HF, Phinney DL, Ryerson FJ (1994) Rutile-aqueous fluid partitioning of $\mathrm{Nb}$, Ta, Hf, $\mathrm{Zr}$, $\mathrm{U}$ and Th: implications for high-field strength element depletions in island arc basalts. Earth Planet Sci Lett 128:327-339

Brenan JM, Shaw HF, Ryerson FJ, Phinney DL (1995) Mineral-aqueous fluid partitioning of trace elements at $900{ }^{\circ} \mathrm{C}$ and $2.0 \mathrm{GPa}$ : Constraints on the trace element chemistry of mantle and deep crustal fluids. Geochim Cosmochim Acta 59:3331-3350

Bureau H, Keppler H (1999) Complete miscibility between silicate melts and hydrous fluids in the upper mantle: experimental evidence and geochemical implications. Earth Planet Sci Lett 165:187-196

Carter L, Skora S, Blundy JD, De Hoog JCM, Elliott T (2015) An experimental study of trace element fluxes from subducted oceanic crust. J Petrol 56:1585-1606 
Class C, Miller DM, Goldstein SL, Langmuir CH (2000) Distinguishing melt and fluid subduction components in Umnak Volcanics, Aleutian Arc. Geochem Geophys Geosyst 1: Article Number 1004

Cruz MF, Manning CE (2015) Experimental determination of quartz solubility and melting in the system $\mathrm{SiO}_{2}-\mathrm{H}_{2} \mathrm{O}-\mathrm{NaCl}$ at $15-20$ kbar and $900-1100{ }^{\circ} \mathrm{C}$ : implications for silica polymerization and the formation of supercritical fluids. Contrib Mineral Petrol 170:35

Elliott T, Plank T, Zindler A, White W, Bourdon B (1997) Element transport from slab to volcanic front at the Mariana arc. J Geophys Res Solid Earth 102:14991-15019

Ferrando S, Petrelli M, Frezzotti ML (2019) Gradual and selective trace element enrichment in slab released fluids at sub-arc depths. Sci Rep 9:16393

Gale A, Dalton CA, Langmuir CH, Su Y, Schilling JG (2013) The mean composition of ocean ridge basalts. Geochem Geophys Geosyst $14: 489-518$

Galvez ME, Connolly JAD, Manning CE (2016) Implications for metal and volatile cycles from the $\mathrm{pH}$ of subduction zone fluids. Nature 539:420-424

Gill J (1981) Orogenic andesites and plate tectonics. Springer, Berlin

Goltz AE, Krawczynski MJ, Gavrilenko M, Gorbach NV, Ruprecht $\mathrm{P}$ (2020) Evidence for superhydrous primitive arc magmas from mafic enclaves at Shiveluch volcano, Kamchatka. Contrib Mineral Petrol 175:115

Green TH, Ringwood TE (1968) Genesis of the calc-alkaline igneous rock suite. Contrib Mineral Petrol 18:105-162

Hawkesworth CJ, Turner SP, McDermott F, Peate DW, van Calsteren $P$ (1997) U-Th isotopes in arc magmas: implications for element transfer from the subducted crust. Science 276:551-555

Hawkesworth C, Cawood PA, Dhuime B (2019) Rates of generation and growth of the continental crust. Geosci Front 10:165-173

Hermann J (2002) Allanite: thorium and light rare earth element carrier in subducted crust. Chem Geol 192:289-306

Hermann J, Rubatto D (2009) Accessory phase control on the trace element signature of sediment melts in subduction zones. Chem Geol 265:512-526

Hermann J, Spandler C, Hack A, Korsakov AV (2006) Aqueous fluids and hydrous melts in high-pressure and ultra-high pressure rocks: implications for element transfer in subduction zones. Lithos 92:399-417

Hofmann AW (1988) Chemical differentiation of the Earth: the relationship between mantle, continental crust, and oceanic crust. Earth Planet Sci Lett 90:297-394

John T, Gussone N, Podladchikov YY, Bebout GE, Dohmen R, Halama R, Klemd R, Magna T, Seitz HM (2012) Volcanic arcs fed by rapid pulsed fluid flow through subducting slabs. Nature Geosci 5:489-492

Johnson KTM (1994) Experimental cpx/ and garnet/melt partitioning of REE and other trace elements at high pressures; petrogenetic implications. Mineral Mag 58:454-455

Johnson MC, Plank T (1999) Dehydration and melting experiments constrain the fate of subducted sediments. Geochem Geophys Geosyst 1: Article Number: 1007

Kawamoto T, Yoshikawa M, Kumagai Y, Mirabueno MHT, Okuno M, Kobayashi T (2013) Mantle wedge infiltrated with saline fluids from dehydration and decarbonation of subducting slab. Proc Nat Acad Sci USA 110:9663-9668

Kawamoto T, Mibe K, Bureau H, Reguer S, Mocuta C, Kubsky S, Thiaudiere D, Ono S, Kogiso T (2014) Large-ion lithophile elements delivered by saline fluids to the sub-arc mantle. Earth Planets Space. https://doi.org/10.1186/1880-5981-66-61

Kelemen PB, Hanghøj K, Greene AR (2005) One view of the geochemistry of subduction-related magmatic arcs, with an emphasis on primitive andesite and lower crust. In: Rudnick RL (ed)
Treatise of Geochemistry, vol 3. The Crust, Elsevier, Amsterdam, pp 593-659

Kelley KA, Cottrell E (2009) Water and the oxidation state of subduction zone magmas. Science 325:605-607

Keppler H (1996) Constraints from partitioning experiments on the composition of subduction-zone fluids. Nature 380:237-240

Keppler H (2017) Fluids and trace element transport in subduction zones. Am Mineral 102:5-20

Keppler H, Wyllie PJ (1990) Role of fluids in transport and fractionation of uranium and thorium in magmatic processes. Nature 348:531-533

Keppler H, Frost DJ (2005) Introduction to minerals under extreme conditions. EMU Notes Mineral 7: 1-30

Kessel R, Ulmer P, Pettke T, Schmidt MW, Thompson AB (2004) A novel approach to determine high-pressure high-temperature fluid and melt compositions using diamond-trap experiments. Am Mineral 89:1078-1086

Kessel R, Schmidt MW, Ulmer P, Pettke T (2005) Trace element signature of subduction-zone fluids, melts and supercritical liquids at $120-180 \mathrm{~km}$ depth. Nature $437: 724-727$

Klaver M, Lewis J, Parkinson IJ, Elburg MA, Vroon PZ, Kelley KA, Elliott T (2020) Sr isotopes in arcs revisited: tracking slab dehydration using $\delta^{88 / 86} \mathrm{Sr}$ and ${ }^{87} \mathrm{Sr} /{ }^{86} \mathrm{Sr}$ systematics of arc lavas. Geochim Cosmochim Acta 288:101-119

Klein-BenDavid O, Izraeli ES, Hauri E, Navon O (2007) Fluid inclusions in diamonds from the Diavik mine, Canada and the evolution of diamond-forming fluids. Geochim Cosmochim Acta 71:723-744

Klemme S, Blundy JD, Wood BJ (2002) Experimental constraints on major and trace element partitioning during partial melting of eclogite. Geochim Cosmochim Acta 66:3109-3123

Konzett J, Frost DJ (2009) The high P-T stability of hydroxyl-apatite in natural and simplified MORB - an experimental study to 15 GPa with implications for transport and storage of phosphorus and halogens in subduction zones. J Petrol 50:2043-2062

Mallik A, Nelson J, Dasgupta R (2015) Partial melting of fertile peridotite fluxed by hydrous rhyolitic melt at 2-3 GPa: implications for mantle wedge hybridization by sediment melt and generation of ultrapotassic magmas in convergent margins. Contrib Mineral Petrol 169: Article Number 48

Mallmann G, O'Neill HSC (2009) The crystal/melt partitioning of V during mantle melting as a function of oxygen fugacity compared with some other elements (Al, P, Ca, Sc, Ti, Cr, Fe, Ga, Y, Zr and $\mathrm{Nb})$. J Petrol 50:1765-1794

Mandler BE, Grove TL (2016) Controls on the stability and composition of amphibole in the Earth's mantle. Contrib Mineral Petrol 171: Article number 68

Manning CE, Frezzotti ML (2020) Subduction-zone fluids. Elements 16:395-400

Meltzer A, Kessel R (2020) Modelling garnet-fluid partitioning in $\mathrm{H}_{2} \mathrm{O}$-bearing systems: a preliminary statistical attempt to extend the crystal lattice-strain theory to hydrous systems. Contrib Mineral Petrol 175:80

Métrich N, Wallace PJ (2008) Volatile abundances in basaltic magmas and their degassing paths tracked by melt inclusions. Rev Mineral Geochem 69:363-402

Mierdel K, Keppler H, Smyth JR, Langenhorst F (2007) Water solubility in aluminous orthopyroxene and the origin of Earth's asthenosphere. Science 315:364-368

Peacock SM (1990) Fluid processes in subduction zones. Science 248:329-337

Pearce JA, Stern RJ, Bloomer SH, Fryer P (2005) Geochemical mapping of the Mariana arc-basin system: implications for the nature and distribution of subduction components. Geochem Geophys Geosyst 6:Q07006 
Plank T (2005) Constraints from thorium/lanthanum on sediment recycling at subduction zones and the evolution of the continents. J Petrol 46:921-944

Plank T, Langmuir CH (1988) The chemical composition of subducting sediment and its consequences for the crust and mantle. Chem Geol 145:325-394

Plümper O, John T, Podladchikov YY, Vrijmoed JC, Scambelluri M (2017) Fluid escape from subduction zones controlled by channelforming reactive porosity. Nature Geosci 10:150-156

Portnyagin M, Hoernle K, Plechov P, Mironov N, Khubunaya S (2007) Constraints on mantle melting and composition and nature of slab components in volcanic arcs from volatiles $\left(\mathrm{H}_{2} \mathrm{O}, \mathrm{S}, \mathrm{Cl}, \mathrm{F}\right)$ and trace elements in melt inclusions from the Kamchatka Arc. Earth Planet Sci Lett 255:53-69

Rapp RP, Shimizu N, Norman MD (2003) Growth of early continental crust by partial melting of eclogite. Nature 425:605-609

Rustioni G, Audétat A, Keppler H (2019) Experimental evidence for fluid-induced melting in subduction zones. Geochem Persp Lett 11:49-54

Rustioni G, Audétat A, Keppler H (2021) A systematic assessment of the diamond trap method for measuring fluid compositions in high-pressure experiments. Am Mineral 106:28-37

Saal AE, Hauri EH, Langmuir CH, Perfit MR (2002) Vapour undersaturation in primitive mid-ocean-ridge basalt and the volatile content of Earth's upper mantle. Nature 419:451-455

Salters VJM, Stracke A (2004), Composition of the depleted mantle. Geochem Geophys Geosyst 5: Article Number 5

Salters VJM, Longhi JE, Bizimis M (2002) Near mantle solidus trace element partitioning at pressures up to $3.4 \mathrm{GPa}$. Geochem Geophys Geosyst 3: Article Number 7

Schmidt MW, Jagoutz O (2017) The global systematics of primitive arc melts. Geochem Geophys Geosyst 18:2817-2854

Schmidt MW, Poli S (1998) Experimentally based water budgets for dehydrating slabs and consequences for arc magma generation. Earth Planet Sci Lett 163:361-379

Sisson TW, Kelemen PB (2018) Near-solidus melts of MORB + 4 $\mathrm{wt} \% \mathrm{H}_{2} \mathrm{O}$ at $0.8-2.8 \mathrm{GPa}$ applied to issues of subduction magmatism and continent formation. Contrib Mineral Petrol 173: Article number 70

Skora S, Blundy J (2010) High-pressure hydrous phase relations of radiolarian clay and implications for the involvement of subducted sediment in arc magmatism. J Petrol 51:2211-2243

Skora S, Blundy JD, Brooker RA, Green ECR, de Hoog JCM, Connolly JAD (2015) Hydrous phase relations and trace element partitioning behaviour in calcareous sediments at subduction-zone conditions. J Petrol 56:953-980

Spandler C, Pirard C (2013) Element recycling from subducting slabs to arc crust: a review. Lithos 170-171:208-223
Stalder R, Foley SF, Brey GP, Horn I (1998) Mineral aqueous fluid partitioning of trace elements at $900-1200{ }^{\circ} \mathrm{C}$ and $3.0-5.7 \mathrm{GPa}$ : new experimental data for garnet, clinopyroxene, and rutile, and implications for mantle metasomatism. Geochim Cosmochim Acta 62:1781-1801

Straub SM, Layne GD (2003) The systematics of chlorine, fluorine, and water in Izu arc front volcanic rocks: implications for volatile recycling in subduction zones. Geochim Cosmochim Acta 67:4179-4203

Sun C, Liang Y (2012) Distribution of REE between clinopyroxene and basaltic melt along a mantle adiabat: effects of major element composition, water, and temperature. Contr Mineral Petrol 163:807-823

Syracuse EM, van Keken PE, Abers GA (2010) The global range of subduction zone thermal models. Phys Earth Planet Interiors 183:73-90

Tatsumi Y (1989) Migration of fluid phases and genesis of basalt magmas in subduction zones. J Geophys Res 94:4697-4707

Tropper P, Manning CE, Harlov DE (2011) Solubility of $\mathrm{CePO}_{4}$ monazite and $\mathrm{YPO}_{4}$ xenotime in $\mathrm{H}_{2} \mathrm{O}$ and $\mathrm{H}_{2} \mathrm{O}-\mathrm{NaCl}$ at $800{ }^{\circ} \mathrm{C}$ and 1 $\mathrm{GPa}$ : implications for REE and $\mathrm{Y}$ transport during high-grade metamorphism. Chem Geol 282:58-66

Tsay A, Zajacz Z, Sanchez-Valle C (2014) Efficient mobilization and fractionation of rare-earth elements by aqueous fluids upon slab dehydration. Earth Planet Sci Lett 398:101-112

Tsay A, Zajacz Z, Ulmer P, Sanchez-Valle C (2017) Mobility of major and trace elements in the eclogite-fluid system and element fluxes upon slab dehydration. Geochim Cosmochim Acta 198:70-91

Turner S, Foden J (2001) U, Th and Ra disequilibria, Sr, Nd and Pb isotope and trace element variations in Sunda arc lavas: predominance of a subducted sediment component. Contrib Mineral Petrol 142:43-57

Weiss Y, McNeill J, Pearson DG, Nowell GM, Ottley CJ (2015) Highly saline fluids from a subducting slab as the source for fluid-rich diamonds. Nature 524:339-342

Zack T, John T (2007) An evaluation of reactive fluid flow and trace element mobility in subducting slabs. Chem Geol 239:199-216

Zamboni D, Gazel E, Ryan JG, Cannatelli C, Lucchi F, Atlas ZD, Trela J, Mazza SE, De Vivo B (2016) Contrasting sediment melt and fluid signatures for magma components in the Aeolian Arc: implications for numerical modeling of subduction systems. Geochem Geophys Geosyst 17:2034-2053

Publisher's Note Springer Nature remains neutral with regard to jurisdictional claims in published maps and institutional affiliations. 